\title{
Assessing pollution in marine protected areas: the role of a multi-biomarker and multi-organ approach
}

\author{
Paloma Kachel Gusso-Choueri ${ }^{1,2,3}$ - Rodrigo Brasil Choueri ${ }^{4}$. \\ Giuliana Seraphim de Araújo ${ }^{3,5}$ - Ana Carolina Feitosa Cruz ${ }^{3,5}$. \\ Tatiana Stremel ${ }^{6}$ - Sandro Campos ${ }^{6}$ - Denis Moledo de Sousa Abessa ${ }^{3}$. \\ Ciro Alberto Oliveira Ribeiro ${ }^{1,3}$
}

Received: 14 November 2014 / Accepted: 16 June 2015 / Published online: 15 July 2015

(C) Springer-Verlag Berlin Heidelberg 2015

\begin{abstract}
Marine protected areas (MPAs) are vulnerable to many pressures, including pollution. However, environmental quality monitoring in these areas traditionally relies on only water chemistry and microbiological parameters. The goal of the current study was to investigate the role of a set of biomarkers in different target organs (liver, kidney, and gills) of fish in order to assess the environmental quality of an MPA (MTs, GPx, GST, GSH, DNA damage, LPO, AChE, and condition index). Chemical analyses were also performed on liver and muscle tissues to evaluate metal body burdens, and PAHs were identified in bile. A demersal fish (Cathorops spixii) that is widely consumed by the local population was used as bioindicator species, and the results were integrated using
\end{abstract}

Responsible editor: Philippe Garrigues

Paloma Kachel Gusso-Choueri

pgusso@yahoo.com.br

1 Post-Graduation Program in Ecology and Conservation, Universidade Federal do Paraná, P.O. Box 19031, CEP 81531-990 Curitiba, PR, Brazil

2 Laboratório de Toxicologia Celular, Departamento de Biologia Celular, Universidade Federal do Paraná, CP19031, 81531-990 Curitiba, PR, Brazil

3 NEPEA, Campus do Litoral Paulista, Universidade Estadual Paulista Júlio de Mesquita Filho, Praça Infante Dom Henrique, s/n, CP 11330-900 São Vicente, SP, Brazil

4 Departamento de Ciências do Mar, Universidade Federal de São Paulo, Av. Almirante Saldanha da Gama, 89, CP 11030-490 Santos, SP, Brazil

5 Instituto Oceanográfico, Universidade de São Paulo, Praça do Oceanográfico, 191, CP 05508-120 São Paulo, SP, Brazil

6 Post-Graduation Program in Applied Chemistry, Universidade Estadual de Ponta Grossa, Av. General Carlos Cavalcanti, 4748 Uvaranas, CP 84030-900 Ponta Grossa, PR, Brazil multivariate analysis. The use of the biomarker approach allowed for the identification of both seasonal and spatial variations in pollution sources around the Environmental Protected Area of Cananéia-Iguape-Peruíbe (APA-CIP). Higher metal body burdens associated with biological responses were found in the sites under the influence of urban areas during the dry season, and they were found in the sites under the influence of the Ribeira de Iguape River (RIR) during the rainy season. The liver was found to be more responsive in terms of its antioxidant responses, whereas gills were found to be more responsive to biomarkers of effect. These results show that this set of biomarker analyses in different organs of fish is a useful tool for assessing chemical pollution in an MPA.

Keywords Environmental monitoring · Contamination . Metal body burdens - PAHs metabolites in bile $\cdot$ Oxidative stress $\cdot$ Neurotoxicity $\cdot$ Genotoxicity $\cdot$ WOE approach

$\begin{array}{ll}\text { Abbreviations } \\ \text { AChE } & \text { Acetylcholinesterase } \\ \text { APA- } & \text { Environmental Protected Area of Cananéia-Iguape- } \\ \text { CIP } & \text { Peruíbe } \\ \text { D } & \text { Dry season } \\ \text { FA/ } & \text { Factor analysis (with principal component analysis } \\ \text { PCA } & \text { as the extraction method) } \\ \text { GPx } & \text { Glutathione peroxidase } \\ \text { GSH } & \text { Non-protein reduced thiols } \\ \text { GST } & \text { Glutathione } S \text {-transferase } \\ \text { LPO } & \text { Lipid peroxidation } \\ \text { MPAs } & \text { Marine protected areas } \\ \text { MTs } & \text { Metallothionein-like protein } \\ \text { P } & \text { Partially dry season } \\ \text { PAHs } & \text { Polycyclic aromatic hydrocarbons }\end{array}$


R Rainy season

RIR Ribeira de Iguape River

\section{Introduction}

Marine protected areas (MPAs) have been established to preserve the marine environment (Scherl et al. 2006). The rationale behind the MPA concept is that by reducing habitat loss and mortality due to anthropogenic pressures, individuals can survive longer and produce more offspring, and populations can grow. However, MPAs are usually planned, created, and managed following the same concepts and theories historically used for terrestrial protected areas, despite the substantial differences in ecosystem processes, historical perceptions, and regulatory frameworks between marine and terrestrial environments (Houde 2001). For example, marine populations, communities, and ecosystems are all connected to a broader landscape and seascape: holoplanktonic organisms, the early life stages of several species, diadromous fish, many forage fish species, and highly migratory species can all travel for long distances to settle, spawn, feed, or nurse (UNCLOS 1982; Carr et al. 2003).

Furthermore, water rarely respects man-made boundaries, and contaminants may be introduced into an MPA from adjacent areas (Palmer et al. 1996; Boersma and Parrish 1999; Pozo et al. 2009). It is widely accepted that MPAs are vulnerable to pollution as well as to fishing, habitat alteration, and climate change (Cicin-Sain and Belfiore 2005; Keller et al. 2009).

Most biological assessments carried out in MPAs consider only direct or indirect effects of fishing on the biota (refer to García Charton et al. 2000; Fraschetti et al. 2002 for reviews). Still, pollution studies in MPAs usually focus on measuring contaminant levels in environmental matrices such as water, sediments, and organisms (e.g., Michel et al. 2001; Conti and Cecchetti 2003; Chou et al. 2004; Pozo et al. 2009; Perra et al. 2011; King et al. 2013; García-Alvarez et al. 2014) rather than the effects of pollutants on the biota that is supposed to be protected (e.g., Terlizzi et al. 2004; Pinsino et al. 2008; Rodrigues et al. 2013; Araujo et al. 2013; Cruz et al. 2014).

The knowledge of the chemical concentrations in a given environment provides important information on the risks of pollution. However, chemical data alone is not capable of providing information on biological effects since the bioavailability and toxicity of chemicals in complex mixtures may be altered as a result of both contaminant synergies (Beyer et al. 2014) and interactions between contaminants and environmental conditions (Chapman and Wang 2001). Thus, the use of ecotoxicological tools (i.e., biological-based assessment tools) is imperative in order to directly assess the health of aquatic organisms within an MPA since these tools shift the focus of the assessment from the agents (contaminants) to the targets (biological/ecological responses).

Effects of pollution are particularly difficult to assess in MPAs since such areas are usually subjected to low to moderate levels of contamination and biological or ecological responses are therefore not as evident (Choueri et al. 2009). Under these unfavorable conditions, effects may not necessarily be lethal, but the conditions can deteriorate the health status of the biota and can affect populations in the long term. Sensitive biological responses are potentially suitable tools for monitoring the environmental quality of mildly contaminated MPAs.

Biochemical and cellular responses measured in organisms' tissues (i.e., biomarkers) can determine the health status of an individual and thus aid in the detection of the first signs of injury caused by pollutants. Biomarkers combined with metal body burdens of resident organisms have been widely used in aquatic pollution monitoring (Van der Oost et al. 2003; Au 2004; Giarratano et al. 2010; Duarte et al. 2011; Oliva et al. 2012, 2014; Barhoumi et al. 2014; Morachis-Valdez et al. 2015), though most biomarker-based environmental quality studies were performed exclusively in highly anthropized sites (Malins et al. 2006; Ramos-Gómez et al. 2011; Ben Ameur et al. 2012; Maranho et al. 2012; Pereira et al. 2014). We hypothesize that biomarkers are adequate for assessing the environmental quality of MPAs.

The evaluation of MPA performance is critical not only for the protection biodiversity itself but also because the failure of MPAs could erode public and political support for conservation (Mora and Sale 2011). The goal of the current study was to investigate the usefulness of a set of biomarkers (antioxidants responses, DNA damage, lipid peroxidation, metal body burdens in different organs, and total PAHs in bile) in the local fish in order to assess environmental quality of an MPA subjected to moderate levels of contamination. To achieve that, biological responses in a demersal fish (Cathorops spixii) that is widely consumed by the local population was used as a bioindicator of pollution.

\section{Materials and methods}

\section{Study area}

The Cananéia-Iguape-Peruíbe Environmental Protected Area (known as the APA-CIP) $\left(24^{\circ} 40^{\prime} \mathrm{S}\right.$ and $\left.25^{\circ} 05^{\prime} \mathrm{S}\right)$ is an estuarine-lagoon ecosystem recognized by UNESCO as part of the Biosphere Reserve of the Atlantic Rainforest due to its relevance for environmental conservation. Since 2000, the region has been part of the global list of UNESCO's World Heritage Sites; in addition, the APA-CIP is considered an area of priority for future inclusion on the list of Brazilian wetlands 
of international importance within the scope of the Ramsar Convention (Brazil 2012).

Two well-defined climate seasons dominate in this region, a drier winter and a rainier summer, with minimum precipitation rates occurring from July to August (monthly average of $95.3 \mathrm{~mm}$ ) and maximum rates from January to March (monthly average of $266.9 \mathrm{~mm}$ ). Monthly mean temperatures range from a maximum of $28^{\circ} \mathrm{C}$ (February) to a minimum of $20^{\circ} \mathrm{C}$ (July). Tides are semidiurnal, and mean tidal amplitude is $0.82 \mathrm{~m}$ (Cunha-Lignon et al. 2009).

The main freshwater contributor to the CIP estuary is the Ribeira de Iguape River (RIR). Approximately $70 \%$ of the course of the river flows toward the lagoon waters through an artificial channel known locally as Valo Grande. The river basin is a metallogenic province with natural $\mathrm{Pb}$ and $\mathrm{Zn}$ deposits (Moraes 2004). Mining activities were performed in this area for many decades during the twentieth century, but the mines were closed down in the 1990s. Since then, high levels of metals ( $\mathrm{Pb}, \mathrm{Zn}, \mathrm{Cu}, \mathrm{Cr}$ ) and arsenic (As) have been recorded in the river waters as well as in both bottom and suspended sediments (Eysink et al. 1988; Corsi and Landim 2003; Moraes 2004; Guimarães and Sígolo 2008). In the estuarine sediments, metals were found at only moderate levels (Mahiques et al. 2009) as defined by the international Sediment Quality Guidelines (Long et al. 1995; Environment Canada and Ministère du Développement durable, de l'Environnement et des Parcs du Québec, 2007).

Apart from its important natural features, the APA-CIP also encompasses three cities (Iguape, 30,259 inhabitants; Ilha Comprida, 9025 inhabitants; Cananéia, 12,601 inhabitants) (IBGE 2014) that lack proper sanitation infrastructure. Waste is discharged in rivers, in groundwater, or directly into the lagoon system since treatment is insufficient for local demand (Morais and Abessa 2014).

\section{Fish collection and sample preparation}

The madamango sea catfish (Cathorops spixii) is a demersal fish that lives in a wide salinity range and preys mainly upon zoobenthos (crustaceans and polychaetes in particular) and small fishes (Fishbase 2014). Adult individuals migrate from coastal zones to lower reaches of estuaries to spawn and the early juvenile development occurs in bays and estuaries (Araújo 1988). In addition to its ecological relevance, this species is of socioeconomic interest as it is widely consumed by the local population (Favaro et al. 2005).

Fifteen specimens of $C$. spixii were collected at each sampling site using a bottom otter trawl (2-min trawling) and kept for the analyses (Fig. 1). Five animals were set aside for metal body burden analyses and ten specimens were set aside for biomarker analyses. Mean length of the animals from all sampling sites was $17.5 \mathrm{~cm}( \pm 3.6)$, and mean weight was $76.3 \mathrm{~g}$ $( \pm 27.9)$. To account for seasonal variation, individuals were collected during three seasons with different amounts of rainfall: (1) the partially dry season (P) (May 2012), (2) the dry season (D) (August 2012), and (3) the rainy season (R) (March 2013). The average rainfall during these seasons was 192, 111, and $390 \mathrm{~mm}$, respectively (CEPAGRI 2014). In the first sampling campaign (during the partially dry season), four sampling stations distributed along the APA-CIP area (P2 to P5) were set up. In the subsequent campaigns, two additional sampling stations were included (P1 and P6) in order to enable a better understanding of the influence of important contaminants sources in APA-CIP. The scope of metal body burdens analyses in C. spixii was enlarged as well. Metal analyses were limited to axial muscle in the first sampling campaign, but liver was included in the subsequent campaigns (dry and rainy seasons). Before dissection, the collected specimens were kept in local water, under aeration until transportation to the laboratory. Before euthanized by spinal cord section, individuals were anesthetized with benzocaine in water, then weighed and measured. Fish gills, kidney, liver, bile, and axial muscle tissues were dissected, frozen, and stored at $-80{ }^{\circ} \mathrm{C}$ until biochemical analyses. Axial muscle and liver tissues used in metal body burden analyses were stored in plastic vessels at $-20{ }^{\circ} \mathrm{C}$.

\section{Condition factor}

Fulton's condition factor was calculated according to the formula: $\mathrm{KF}=\left(W / L^{3} \times 100\right)$, where $\mathrm{KF}=$ Fulton condition factor, $W=$ body weight in grams, and $L=$ total body length in centimeters.

\section{Biochemical determinations}

Gills, kidney, liver, and muscle tissues were kept on ice and homogenized at $10 \% \mathrm{w} / \mathrm{v}$ in Tris- $\mathrm{HCl}$ buffer (Tris $50 \mathrm{mM}$; EDTA $1 \mathrm{mM}$; DTT $1 \mathrm{mM}$; sucrose $50 \mathrm{mM}$; KCl $150 \mathrm{mM}$; PMSF $1 \mathrm{mM}, \mathrm{pH} 7.6$ ). Homogenates were centrifuged at 10, $000 \times g$ for $20 \mathrm{~min}$ at $4{ }^{\circ} \mathrm{C}$, and in the case of the liver, gills, and kidney, aliquots of the supernatants were kept for the analyses of glutathione $S$-transferase (GST) and glutathione peroxidase (GPx) activities as well as for the quantification of non-protein reduced thiols (GSH), lipid peroxidation (LPO), and DNA strand breaks. In the case of the muscle tissue, supernatants were used for acetylcholinesterase (AChE) activity analyses. Liver, kidney, and gill tissue samples were also set aside for metallothionein-like protein (MTs) analysis, homogenized with $20 \mathrm{mM}$ Tris- $\mathrm{HCl}$ buffer supplemented with $0.5 \mathrm{M}$ sucrose, $0.01 \% \beta$-mercaptoethanol, and centrifuged at 15 , $000 \times g$ for $30 \mathrm{~min}$ at $4{ }^{\circ} \mathrm{C}$.

GST (Keen et al. 1976) and GPx activities (Sies et al. 1979) were determined spectrophotometrically at $340 \mathrm{~nm}$. GSH levels were measured spectrophotometrically at $415 \mathrm{~nm}$ (Sedlak and Lindsay 1968). AChE activity analysis was 


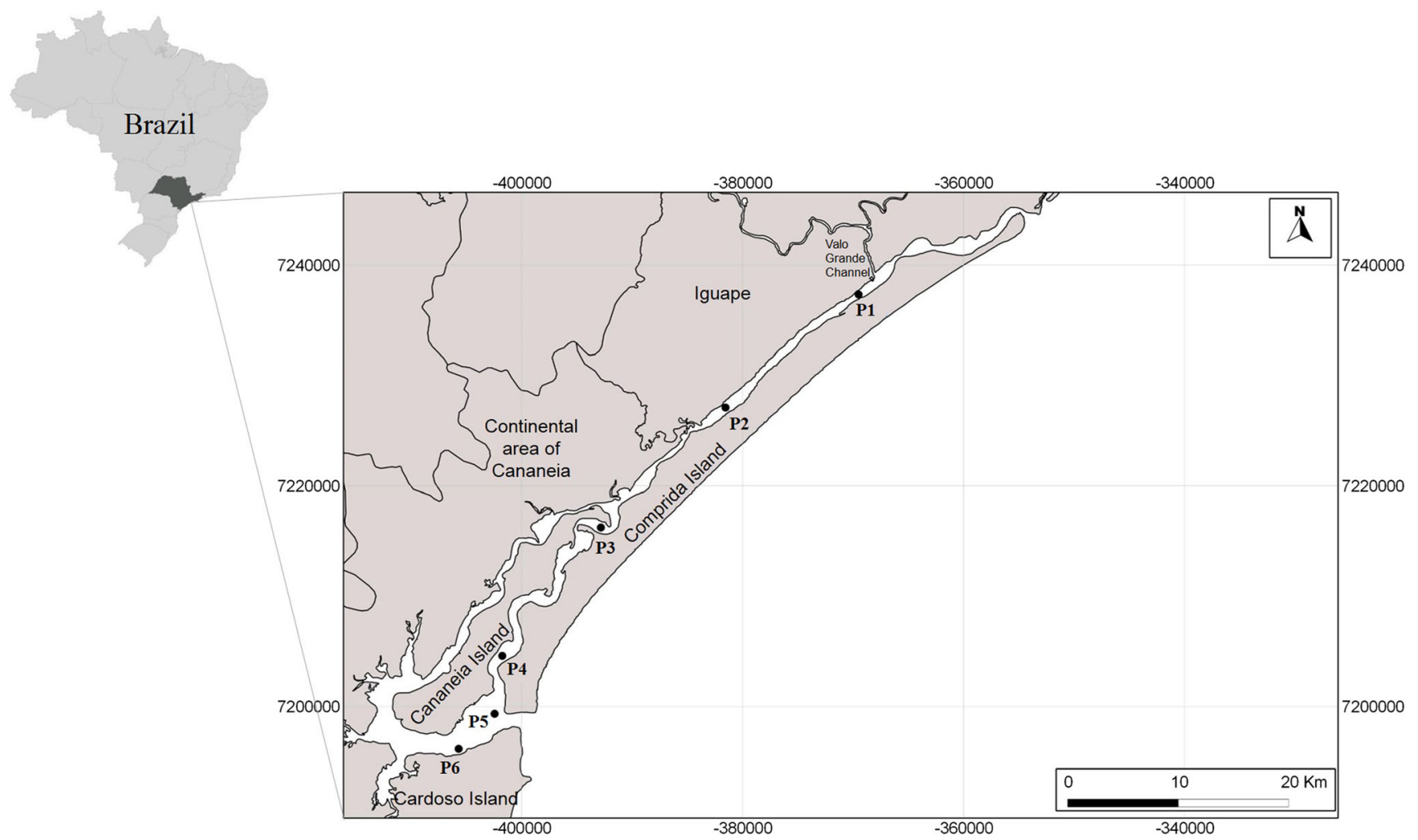

Fig. 1 Sampling stations located within the APA-CIP, Brazil

performed at $415 \mathrm{~nm}$ using the colorimetric method by Ellman et al. (1961). The concentration of metallothionein-like protein (MTs) was established based on cysteine residue titration of a partially purified MT extract obtained by acidic ethanol/ chloroform fractionation of the tissue homogenate. In brief, after the homogenization, cold $\left(-20^{\circ} \mathrm{C}\right)$ absolute ethanol and chloroform were added to the supernatant in order to precipitate the high molecular weight proteins. Samples were then centrifuged at $6000 \times g$ for $10 \mathrm{~min}$ at $4{ }^{\circ} \mathrm{C}$. This supernatant fraction was acidified with $\mathrm{HCl}$ to co-precipitate MT and improve recovery. Before acidification, samples were stored at $-20^{\circ} \mathrm{C}$ for $1 \mathrm{~h}$. The samples were subsequently re-centrifuged at $6000 \times g$ for $10 \mathrm{~min}$ at $4{ }^{\circ} \mathrm{C}$ and the MTs pellet obtained was resuspended with an ethanol/chloroform/homogenizing buffer Tris-HCl $20 \mathrm{nM}$ solution. Samples were re-centrifuged at $6000 \times g$ for $10 \mathrm{~min}$ at $4{ }^{\circ} \mathrm{C}$. The MTs pellet obtained was resuspended in $0.25 \mathrm{M} \mathrm{NaCl}$ solution and then $\mathrm{HCl} / \mathrm{EDTA}$ was added to remove metal cations still bound to the MT.

The MTs-like protein concentration was quantified using Ellman's reagent containing DTNB after a centrifugation of $3000 \times \mathrm{g}$ for $5 \mathrm{~min}$ at room temperature. The absorbance was recorded at $412 \mathrm{~nm}$ (Viarengo et al. 1997).

Levels of lipid peroxidation (LPO) were determined by quantifying the concentration of 2-thiobarbituric acid reactive substrates (TBARS) through fluorescence $\left(\lambda_{\text {ex }} 532 \mathrm{~nm}\right.$ and $\lambda_{\mathrm{em}} 556 \mathrm{~nm}$ ) (Wills 1987). DNA strand breaks were measured using an alkaline precipitation assay (Olive 1988; Gagne and
Blase 1995). The assay is based on the potassium dodecyl sulfate precipitation of protein-bound genomic DNA, which leaves protein-free DNA strand breaks in the supernatant. These DNA strands are quantified using fluorescence $\left(\lambda_{\mathrm{ex}}\right.$ $360 \mathrm{~nm}$ and $\lambda_{\mathrm{em}} 450 \mathrm{~nm}$ ) after staining with Hoechst dye. Standard solutions of salmon sperm DNA were used for calibration. Protein concentrations were determined spectrophotometrically at $595 \mathrm{~nm}$ (Bradford 1976), with BSA as the standard. All biomarkers analyses were performed in a microplate reader (Biotek-Synergy ${ }^{\mathrm{TM}} \mathrm{HT}$ ).

\section{Chemical analyses}

\section{Metal body burden}

Concentrations of As in muscle and liver tissues were determined using an atomic absorption spectrophotometer (Varian ${ }^{\circledR}$, AA 240Z) equipped with a graphite furnace (AAS-GF) (Model, GTA 120). Metals were quantified using flame atomic absorption spectroscopy (FAAS) (Varian ${ }^{\circledR}$, AA 240FS). All analyses were performed according to standard method 200.9 (USEPA 1994). Detection limits for As were $5.88 \mu \mathrm{g} \mathrm{kg}^{-1}$ and detection limits for metals $(\mathrm{Cu}, \mathrm{Mn}, \mathrm{Zn}, \mathrm{Cr}$, $\mathrm{Co}, \mathrm{Ni}, \mathrm{Cd}, \mathrm{Pb}$ ) were $0.034,0.0697,0.0525,0.112,0.146$, $0.0623,0.042$, and $0.0602 \mathrm{mg} \mathrm{kg}^{-1}$, respectively. Standard curves were prepared using reference material (Qhemis High Purity ${ }^{\circledR}$ ). Recovery rates ranged from 80 to $120 \%$ in all 
investigations. Metal concentrations were expressed in milligrams per kilogram of dry weight.

\section{Polycyclic aromatic hydrocarbons in bile}

The metabolites of polycyclic aromatic hydrocarbons (PAHs) in the bile of $C$. spixii were quantified via fixed-wavelength fluorescence in the spectrofluorometer (Sunrise-Tecan) at wavelengths of 288/330, 334/376, 364/406, and 380/422 nm $\left(\lambda_{\text {ex }} / \lambda_{\text {em }}\right)$, which correspond respectively to naphthalene type (two rings), pyrene type (four rings), benzo[a]pyrene-type (five rings), and benzo[ghi]perylene type (six rings) (Aas et al. 2000; Oliveira Ribeiro et al. 2005). PAH concentrations were determined through a comparison with a standard curve for each group of rings. The results were expressed as units of PAH milligrams per protein.

\section{Data treatment}

\section{Statistical analyses}

First, biomarker data and total PAH contents in bile were tested for normality (Kolmogorov-Smirnov's test) and homoscedasticity (Bartlett's method). The statistical differences of mean values of each data series $(n=10)$ that met analysis of variance (ANOVA) assumptions were tested through ANOVA followed by post hoc Tukey's test. Non-parametric statistical tests (Kruskal-Wallis test, with Dunn's multiple comparisons as post-test) were used to compare data series that violated ANOVA assumptions. The significance level was set at $p=$ 0.05 .

The biological data was integrated by two different methods. In the first one, only biological responses data were integrated through the calculation of an index, i.e., the Biomarker Response Index (BRI) (Hagger et al. 2008). Shortly, biomarker data (GST, GSH, GPX, MTs, LPO, DNA damage, and AChE) were ranked numerically to represent varying degrees of severity from normal reference responses. Since there is no baseline biomarker data for C. spixii, the responses obtained in fish from the sampling site showing the least effects and bioaccumulation was deemed the reference condition. The index ranges from numeral ranks of one (severe alterations) to four (no or slight alterations). The biomarkers were also weighted according to their potential of impact on the health of the organisms (i.e., biomarkers of effects weighted as two, while biomarkers of exposure weighted as one). The BRI was calculated as the following (Hagger et al. 2008):

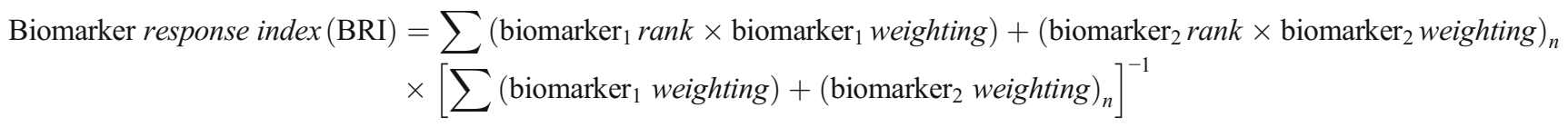

The second integration method aimed to highlight associations among the variables measured in this study (both biomarker responses and bioaccumulation levels) during each of the three seasons (partially dry, dry, and rainy). Factor analysis with principal component analysis as the extraction method (FA/PCA) was used. Associations between the different biomarkers (GST, GSH, GPX, MTs, LPO, DNA damage, and AChE), metal loads ( $\mathrm{Cu}, \mathrm{Mn}, \mathrm{Zn}, \mathrm{Cr}, \mathrm{Co}, \mathrm{Ni}, \mathrm{Cd}, \mathrm{Pb})$ and As loads in liver and muscle tissues, and total PAH metabolites in bile were assessed. The variables that failed to present significant variation among sampling stations were removed from the original datasets. The variables were autoscaled (standardized) so as to be treated with equal importance. The selected variables to be interpreted were those associated with the factors with a loading $\geq 0.50$, a value which is more conservative than the loading cut-off recommended by Tabachnic and Fidell (1996). The relevance of the observed associations to each of the six sampling stations (cases) was estimated by calculating the factor score from each case for the centroid of all cases for the original data. All the statistical and multivariate analyses were performed using STATISTICA 12 software (StatSoft Inc. USA).

\section{Results}

The responses of the biomarkers of exposure in the liver and gills of $C$. spixii specimens collected along the APACIP revealed both seasonal and spatial variations (Fig. 2a-1). During the periods of lower rainfall (dry, partially dry), biomarkers of exposure (MT, GST, GPX, and GSH) presented significantly higher values among the fish collected at the estuarine sections influenced by the city of Cananéia (P4, P5, and P6); during the rainy season, these responses are more pronounced in fish sampled from the region under the influence of the RIR (P1, P2, P3). Biomarkers of effect (LPO, DNA damage, and $\mathrm{AChE}$ ) found in $C$. spixii liver tissue also followed these seasonal and spatial variations (Fig. 3a-g). In addition, liver genotoxicity responses were higher in specimens sampled during the dry and partially dry seasons in the stations under the influence of Cananéia (P4, P5, P6); during the rainy season, LPO levels in the liver were higher ( $p<0.05$, ANOVA). AChE activity was inhibited, particularly in the stations under the influence of the RIR $(p<0.05$, ANOVA). Responses of biomarkers found in 

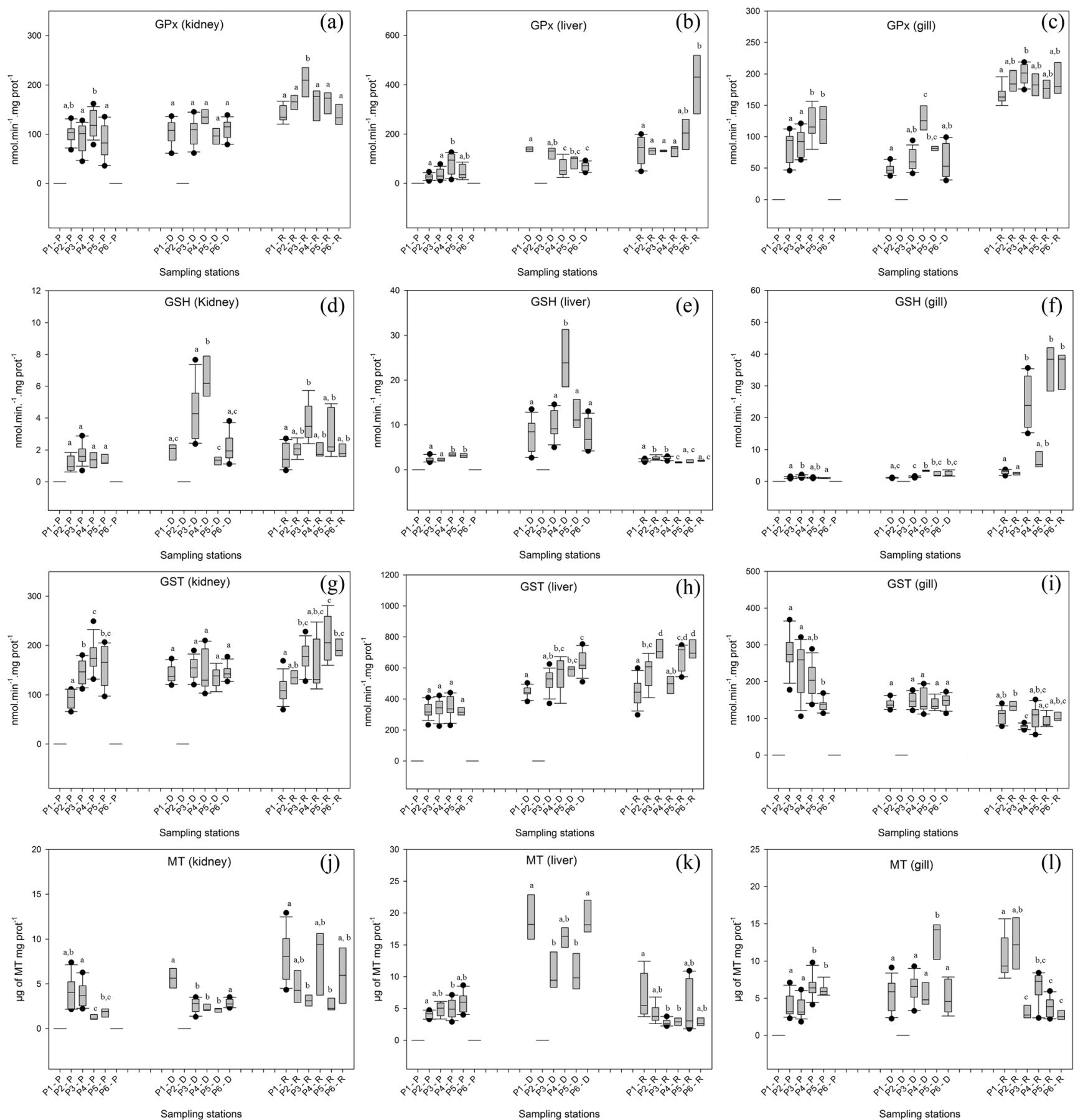

Fig. 2 a-l Responses of biomarkers of exposure in kidney, liver, and gill tissues from Cathorops spixii from the APA-CIP collected during the partially dry season $(P)$, the dry season $(D)$, and the rainy season $(R)$. Sites with a line instead of a boxplot mean that no organisms were sampled. Data are presented as boxes with boundaries that indicate 25 th and

kidney tissue generally followed a pattern of response based on the sample's proximity to the two main sources of contamination (the RIR and Cananéia).

Fulton's condition factor results (Fig. 3h) showed that specimens from P1 (during both the dry season and the rainy season) and P2 (during the rainy season) were more well 75th percentiles; a line within the box marks the median value; whiskers below and above the box indicate 10th and 90th percentiles; the outliers are presented with black dots. The use of different letters above the data indicates significant differences during the same season $(p=0.05)$

nourished ( $p<0.05$, ANOVA). No spatial differences were observed in the partially dry season ( $p>0.05$, ANOVA).

Biological responses were consistent with As and metal concentrations in liver and muscle tissues of $C$. spixii (Fig. 4a-d). In general, As, Mn, Zn, Cd, and $\mathrm{Pb}$ concentrations in muscle were higher in stations closer to the city 

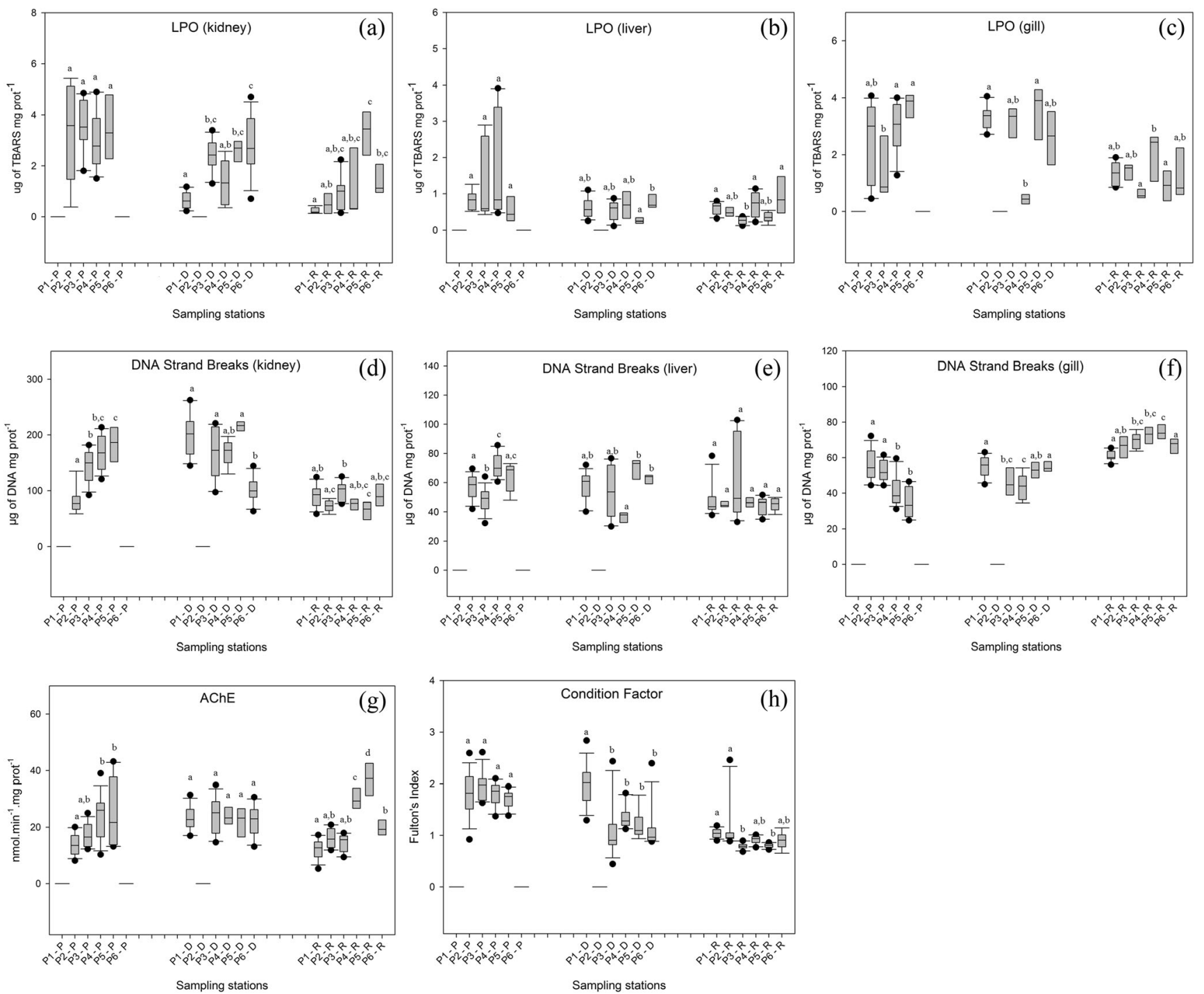

Fig. $3 \mathbf{a}-\mathbf{h}$ Responses of biomarkers of effects in all analyzed tissues and condition factor of Cathorops spixii from the APA-CIP collected during the partially dry season $(P)$, the dry season $(D)$, and the rainy season $(R)$. Sites with a line instead of a boxplot mean that no organisms were sampled. Data are presented as boxes with boundaries that indicate 25th and

75th percentiles; a line within the box marks the median value; whiskers below and above the box indicate 10th and 90th percentiles; the outliers are presented with black dots. The use of different letters above the data indicates significant differences during the same season $(p=0.05)$

(P4, P5, and P6) during the dry season and decreased during the rainy season. The opposite was found in analyses of $\mathrm{Co}$ and $\mathrm{Ni}$ levels in specimens from the station closest to the city (P4): levels were higher during the rainy season. A similar pattern was found in the analyses of metals in liver tissue: in general, metal concentrations in the dry season tended to be elevated in stations closer to the outskirts of the city (P5 and P6), although the station closest to the city (P4) showed higher levels of $\mathrm{As}, \mathrm{Cu}, \mathrm{Co}$, and $\mathrm{Cd}$ during the rainy season compared to the dry season. In analyses of muscle and liver tissues from specimens collected closer to the RIR, higher metal concentrations ( $\mathrm{Mn}, \mathrm{Zn}, \mathrm{Co}, \mathrm{Cr}$, $\mathrm{Ni}$ ) were found during the rainy season than during the dry season (Fig. 4a-d). Exceptions were only $\mathrm{Cd}$ in muscle, and
$\mathrm{Cu}$ and $\mathrm{As}$ in the liver, of which higher concentrations were found during the dry season.

Levels of cadmium (annual means in sampling stations ranging from $<0.11$ to $1.78 \mathrm{mg} \mathrm{kg}^{-1}$ w.w.), lead (from 3.80 to $6.94 \mathrm{mg} \mathrm{kg}^{-1}$ w.w.), and total arsenic (from 0.0004 to $1.45 \mathrm{mg} \mathrm{kg}^{-1}$ w.w.) in the muscle were, in some instances, higher than the levels set by Mercosul (2011) and the Brazilian Sanitary Vigilance Authority (ANVISA 2013) (Brazil 2012) (both established a range from 0.05 to $0.3 \mathrm{mg} \mathrm{kg}^{-1}$ w.w. for $\mathrm{Cd}, 0.3 \mathrm{mg} \mathrm{kg}^{-1}$ w.w. for $\mathrm{Pb}$, and $1.0 \mathrm{mg} \mathrm{kg}^{-1}$ w.w. for total As) as well as $\mathrm{FAO} / \mathrm{WHO}$ (2014) $\left(1.0,2.0\right.$, and $1.0 \mathrm{mg} \mathrm{kg}^{-1}$ w.w. for $\mathrm{Cd}, \mathrm{Pb}$, and total As, respectively) and $\mathrm{EC}(2002,2006)(\mathrm{Cd}=0.1$ to $0.30 \mathrm{mg} \mathrm{kg}^{-1}$ w.w.; $\mathrm{Pb}=0.30 \mathrm{mg} \mathrm{kg}^{-1}$ w.w.). 
Fig. 4 a-d Metal body burdens (muscle and liver) from

Cathorops spixii sampled in the APA-CIP during both the dry season and the rainy season. Data were transformed (square root)

for better visualization
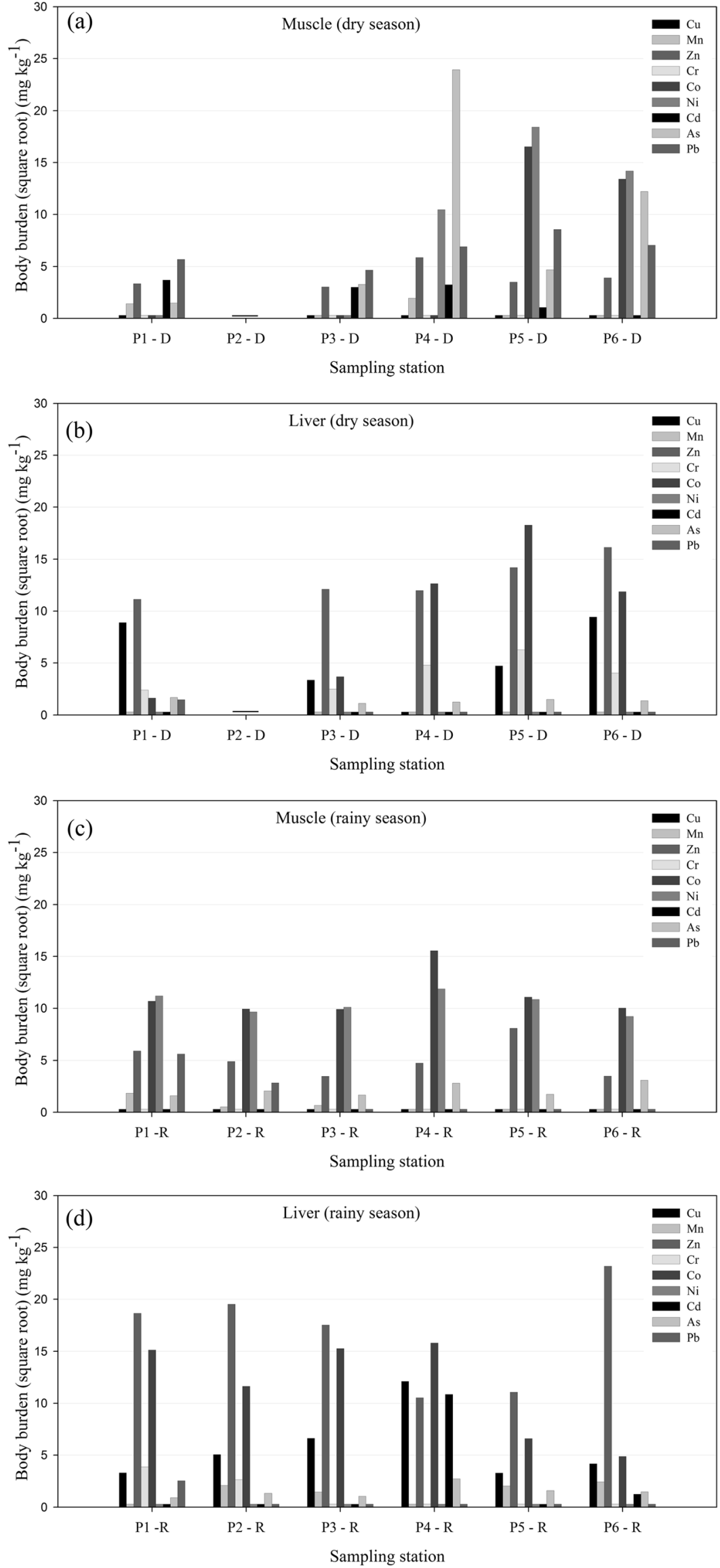
Total PAH metabolites in bile also showed a seasonal trend, with higher concentrations reported during the rainy season ( $p<0.05$, ANOVA) (Fig. 5) for stations under the influence of both the river and the city. During the dry season, there was an increase in total PAH metabolites in bile in specimens from P3 and $\mathrm{P} 4$ compared to the other sampling stations, whereas during the rainy season, specimens from $\mathrm{P} 1$ and $\mathrm{P} 4$ presented higher levels.

The BRI values of each site at each season are presented in Fig. 6. Although the final classification was "no or slight alteration from normal responses" for most sites (following classification provided by Hagger et al. 2008) (exceptions were $\mathrm{P} 1$ and $\mathrm{P} 4$ during rainy season, both showing "moderate alteration"), the values show a trend of presenting more severe responses at sites closer to $\mathrm{P} 1$ and $\mathrm{P} 4$ at all seasons.

Three different datasets were used to perform FA/PCA: samples from the (1) partially dry, (2) dry, and (3) rainy seasons. Total explained variance of each FA/PCA was $100 \%$ for the partially dry season dataset, $87.9 \%$ for the dry season dataset, and $93.4 \%$ for the rainy season dataset.

Three factors were extracted from the original dataset of the partially dry season. The first factor (F1, which explained $62.2 \%$ of the variance) (Table 1) reflected metals ( $\mathrm{Cd}$ and As) found in muscle and associated with MTs in the gills and liver tissues, several antioxidant responses in different organs, and DNA damage in the kidneys. Factor score analysis showed that these associations were more relevant (i.e., presented higher scores) in specimens from stations under the influence of the urban area (P4 and P5) (Table 4). Also in F1, another group of associated variables (with negative values) included $\mathrm{Pb}$ in muscles, $\mathrm{PAH}$ metabolites in bile, MT levels in kidneys, genotoxicity in gills, and neurotoxicity
(AChE inhibition). This group of variables was found to have the highest factor score for $\mathrm{P} 2$, which is the site that is under the greatest influence of the RIR. The second factor (F2, $25.1 \%$ of explained variance) related, in one group, metals in muscle $(\mathrm{Pb}$ and $\mathrm{Zn})$ and antioxidant response in liver and kidney tissues (GPx) (with the highest factor score estimated for P4), and, in another group, levels of Mn were found to be related to MTs in the liver (highest score for P5). The third factor (F3, $12.7 \%$ of explained variance) associated As, Mn, and $\mathrm{Zn}$ levels in muscle tissues, MTs, oxidative damage, and antioxidant response in the gills, in addition to an indication of antioxidant activity and genotoxicity in the liver. This factor shows the highest score for P5, followed by P2 (Table 4). Another group of variables associated with F3 included antioxidants and genotoxic responses in the gills, without, however, any relationship with the contaminants quantified in organisms. These associations are relevant for P3.

Three factors were extracted from the original dry season dataset (Table 2). In one group, F1 (37.8 \% of explained variance) represented metal levels in muscles associated with antioxidant responses (GSH in the kidney, liver and gills, and GPx in the gills) (with highest score for P4). F1 also associated another group of variables: DNA damage and LPO in the gills, DNA damage in liver tissue, and levels of As and $\mathrm{Cu}$ in the liver (highest score for P1, followed by P6). F2 (35.0\%) (Table 2) associated metal levels in the liver $(\mathrm{Cr}$, $\mathrm{Co})$ and muscle $(\mathrm{Pb}, \mathrm{Ni}$, and $\mathrm{Co})$ with increased MTs in gills and genotoxicity in liver and kidney tissues. These associations are highly relevant only in P5 (Table 4). Another group of variables showed a relationship between levels of PAH metabolites in bile and damage in liver cells (genotoxicity and lipid peroxidation) (Table 2). The estimated scores of this
Fig. 5 Total PAH metabolites in the bile of Cathorops spixii sampled in the APA-CIP during the partially dry season $(P)$, the dry season $(D)$, and the rainy season $(R)$. Sites with a line instead of a boxplot means that no organisms were sampled. Data are presented as boxes with boundaries that indicate 25 th and 75th percentiles; a line within the box marks the median value. The use of different letters above the data indicates significant differences during the same season $(p=0.05)$

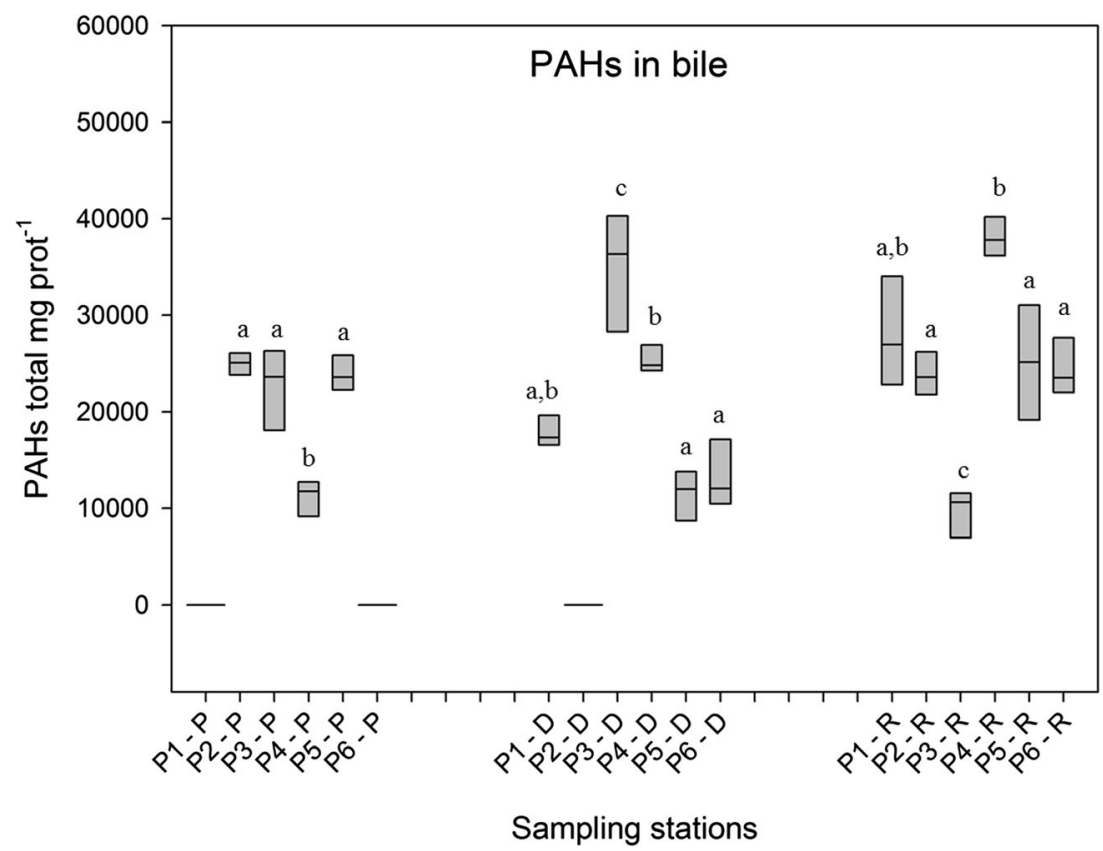


Fig. 6 Biomarker response index estimation for Cathorops spixii sampled in the APA-CIP during the partially dry season $(P)$, the dry season $(D)$, and the rainy season $(R)$. Sites with a line instead of a bar mean that no organisms were sampled. Higher ranks mean lesser difference to baseline conditions

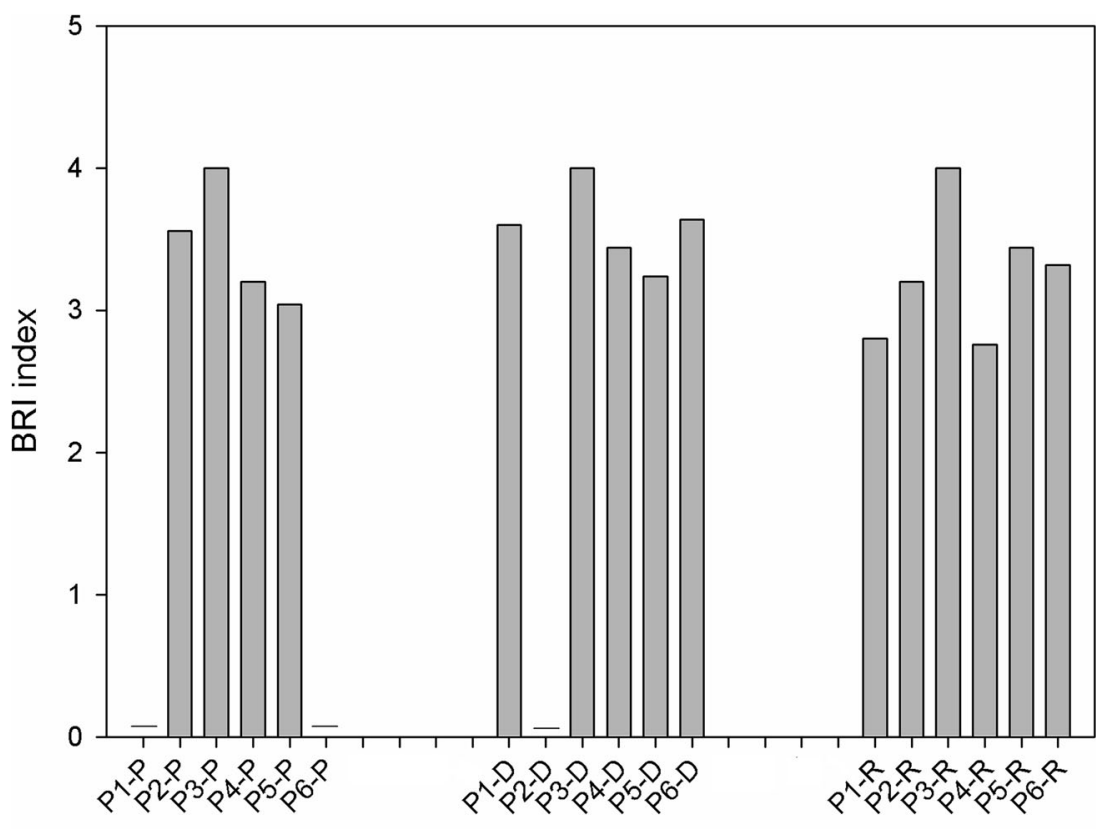

Sampling stations
Table 1 Loadings of partially dry season after varimax rotation for the three factors obtained in the $\mathrm{PCA}^{\mathrm{a}}$ (the variance of the principal factors is given in percentage of the total variance in the original data matrix)

\begin{tabular}{|c|c|c|c|}
\hline Factors & F1 & $\mathrm{F} 2$ & $\mathrm{~F} 3$ \\
\hline$\%$ variance & 62.21 & 25.10 & 12.69 \\
\hline MTs kidney & -0.831 & -0.365 & -0.419 \\
\hline GPx kidney & -0.154 & 0.969 & -0.196 \\
\hline GST kidney & 0.988 & 0.155 & 0.022 \\
\hline DNA damage kidney & 0.974 & -0.224 & 0.033 \\
\hline MTs liver & 0.837 & -0.528 & 0.143 \\
\hline GPx liver & 0.498 & 0.837 & 0.226 \\
\hline GSH liver & 0.770 & 0.285 & 0.571 \\
\hline DNA damage liver & 0.440 & 0.168 & 0.882 \\
\hline MTs gill & 0.754 & 0.278 & 0.594 \\
\hline GPx gill & 0.667 & -0.022 & 0.745 \\
\hline GSH gill & -0.127 & 0.144 & -0.981 \\
\hline GST gill & -0.781 & 0.286 & -0.555 \\
\hline LPO gill & 0.118 & -0.060 & 0.991 \\
\hline DNA damage gill & -0.831 & 0.061 & -0.553 \\
\hline $\mathrm{AChE}$ & -0.858 & -0.477 & -0.189 \\
\hline PAHS in bile & -0.500 & -0.868 & -0.048 \\
\hline Mn muscle & 0.310 & -0.708 & 0.634 \\
\hline Zn muscle & 0.027 & 0.817 & 0.576 \\
\hline Cd muscle & 0.919 & -0.197 & 0.341 \\
\hline As muscle & 0.782 & 0.305 & 0.543 \\
\hline $\mathrm{Pb}$ muscle & -0.564 & 0.766 & -0.309 \\
\hline
\end{tabular}

${ }^{\text {a }}$ Only variables with loadings 0.5 (in bold text) were considered components of the factors factor are especially high for stations P3 and P6 (Table 4). F3 $(15.0 \%)$ revealed strong associations between levels of some metals in the tissues ( $\mathrm{Zn}$ in the liver, $\mathrm{Ni}$ and Co in muscles), oxidative damage in kidney cells, and a decreased condition factor. These responses were particularly relevant for specimens from P6 (Table 4). In other associations with F3, other contaminants in tissues $(\mathrm{Pb}$ and $\mathrm{As}$ in liver tissues and $\mathrm{Cd}$ in muscle tissues) were linked to MTs and genotoxic damage in the kidney, and these associations were relevant for specimens from P1.

Four factors were extracted by the FA/PCA applied to the rainy season dataset (Table 3). F1 (36.9\% of explained variance) reflected the association of metal burdens in the tissues $(\mathrm{Pb}$ in muscle and liver tissues, $\mathrm{Mn}$ in muscle tissues, and $\mathrm{Cr}$ in liver tissues), MTs in the liver and gills, and an indication of antioxidant response in gills (GST) and of neurotoxicity (AChE inhibition). This group of variables was found to have higher scores for the sampling stations under higher influence of the RIR (P1 and P2) (Table 4). Another group of variables was also related to $\mathrm{F} 1: \mathrm{Mn}$ in the liver (associated with decreased condition factor), the presence of DNA damage in the gills, and antioxidant responses in different organs (GSH in the gills and kidneys, GST in the liver and kidneys). These associations are relevant to P3, P4 (moderately), P5, and P6 (Table 4). F2 $(27.1 \%)$ reflects the associations between $\mathrm{Cd}, \mathrm{Co}, \mathrm{Cu}$, and As levels in the liver, $\mathrm{Ni}$ and $\mathrm{Co}$ in muscle tissues, MTs in kidney tissues, lipid peroxidation in the gills, and PAH metabolites in bile (Table 3). Only P4 (the sampling station under highest influence of the urban area) was found to have a high score for this group of variables 
Table 2 Loadings (correlation coefficients) of dry season after varimax rotation for the three factors obtained in the $\mathrm{PCA}^{\mathrm{a}}$ (the variance of the principal factors is given in percentage of the total variance in the original data matrix)

\begin{tabular}{|c|c|c|c|}
\hline Factors & F1 & $\mathrm{F} 2$ & F3 \\
\hline$\%$ variance & 37.782 & 35.024 & 15.048 \\
\hline MTs kidney & -0.528 & -0.326 & -0.736 \\
\hline GSH kidney & 0.868 & -0.429 & -0.057 \\
\hline LPO kidney & -0.204 & 0.309 & 0.833 \\
\hline DNA damage kidney & 0.075 & 0.610 & -0.730 \\
\hline MTs liver & 0.035 & -0.782 & -0.025 \\
\hline GPx liver & -0.691 & 0.013 & -0.573 \\
\hline GSH liver & 0.985 & 0.086 & -0.119 \\
\hline GST liver & 0.352 & 0.294 & 0.881 \\
\hline LPO liver & 0.296 & -0.924 & 0.131 \\
\hline DNA damage liver & -0.842 & 0.519 & 0.143 \\
\hline MTs gills & -0.181 & 0.933 & -0.043 \\
\hline GPX gills & 0.960 & 0.271 & 0.057 \\
\hline GSH gills & 0.911 & 0.096 & 0.292 \\
\hline LPO gills & -0.952 & 0.257 & -0.124 \\
\hline DNA damage gills & -0.897 & 0.136 & -0.036 \\
\hline Condition factor & 0.123 & 0.080 & 0.876 \\
\hline PAHS in bile & 0.370 & -0.626 & -0.233 \\
\hline Mn muscle & 0.757 & -0.195 & -0.490 \\
\hline Zn muscle & 0.923 & -0.069 & 0.078 \\
\hline Co muscle & -0.341 & 0.748 & 0.541 \\
\hline Ni muscle & -0.023 & 0.815 & 0.528 \\
\hline Cd muscle & 0.285 & -0.457 & -0.835 \\
\hline As muscle & 0.920 & -0.150 & 0.146 \\
\hline $\mathrm{Pb}$ muscle & 0.109 & 0.861 & 0.335 \\
\hline $\mathrm{Cu}$ liver & -0.727 & -0.262 & 0.030 \\
\hline Zn liver & -0.327 & 0.203 & 0.865 \\
\hline Cr liver & 0.280 & 0.901 & 0.307 \\
\hline Co liver & 0.204 & 0.879 & 0.402 \\
\hline As liver & -0.501 & 0.318 & -0.571 \\
\hline $\mathrm{Pb}$ liver & -0.396 & -0.192 & -0.830 \\
\hline
\end{tabular}

${ }^{\text {a }}$ Only variables with loadings 0.5 (in bold text) were considered components of the factors

(Table 4). Another group of variables associated with F2 included $\mathrm{Mn}$ and $\mathrm{Zn}$ and antioxidant responses (GST in liver and kidney tissues, and GSH in the gills); high scores were estimated mainly for stations under urban influence (P5 and P6), but also in the case of P3, which is under the influence of RIR. Factor $3(15.7 \%)$ revealed the association of $\mathrm{Zn}$ in the liver and As in muscle tissues, MTs in the kidneys, an indication of antioxidant response (GPx) and oxidative damage (LPO) in the liver, and PAH metabolites in bile. Higher F3 scores were estimated for P4 and P6. F4 $(13.8 \%)$ loadings showed an association of $\mathrm{Zn}$ in muscle and LPO in kidney, and, in another group, $\mathrm{Zn}$ in the liver
Table 3 Loadings (correlation coefficients) of rainy season after varimax rotation for the three factors obtained in the $\mathrm{PCA}^{\mathrm{a}}$ (the variance of the principal factors is given in percentage of the total variance in the original data matrix)

\begin{tabular}{|c|c|c|c|c|}
\hline Factors & $\mathrm{F} 1$ & $\mathrm{~F} 2$ & F3 & $\mathrm{F} 4$ \\
\hline$\%$ variance & 36.873 & 27.110 & 15.656 & 13.754 \\
\hline MTs kidney & 0.432 & -0.663 & 0.523 & -0.106 \\
\hline GPx kidney & -0.492 & -0.183 & -0.830 & -0.186 \\
\hline GSH kidney & -0.503 & 0.220 & -0.724 & -0.415 \\
\hline GST kidney & -0.807 & 0.501 & -0.088 & 0.275 \\
\hline LPO kidney & -0.499 & 0.402 & -0.269 & 0.719 \\
\hline DNA damage kidney & 0.089 & 0.306 & -0.033 & -0.734 \\
\hline MTs liver & 0.991 & 0.067 & -0.009 & 0.118 \\
\hline GPx liver & -0.406 & 0.445 & 0.756 & 0.061 \\
\hline GSH liver & 0.208 & 0.375 & -0.319 & -0.805 \\
\hline GST liver & -0.783 & 0.589 & -0.178 & 0.018 \\
\hline LPO liver & 0.213 & -0.291 & 0.920 & -0.102 \\
\hline MTs gill & 0.704 & -0.296 & 0.050 & -0.076 \\
\hline GPX gill & -0.295 & -0.052 & -0.387 & -0.854 \\
\hline GSH gill & -0.692 & 0.568 & 0.078 & 0.314 \\
\hline GST gill & 0.579 & -0.276 & 0.431 & -0.187 \\
\hline LPO gill & 0.243 & -0.911 & 0.110 & 0.169 \\
\hline DNA damage gill & -0.860 & -0.461 & -0.077 & 0.194 \\
\hline $\mathrm{AChE}$ & 0.534 & 0.329 & 0.050 & -0.777 \\
\hline Condition factor & -0.818 & 0.230 & -0.510 & 0.086 \\
\hline PAHS in bile & 0.206 & -0.671 & 0.534 & 0.464 \\
\hline Mn muscle & 0.925 & 0.124 & -0.069 & -0.015 \\
\hline Zn muscle & 0.129 & 0.128 & -0.291 & 0.932 \\
\hline Co muscle & -0.118 & -0.952 & 0.122 & 0.220 \\
\hline Ni muscle & 0.294 & -0.756 & -0.235 & 0.445 \\
\hline As muscle & -0.446 & -0.281 & 0.835 & -0.136 \\
\hline $\mathrm{Pb}$ muscle & 0.984 & 0.117 & 0.025 & 0.014 \\
\hline $\mathrm{Cu}$ liver & -0.245 & -0.957 & 0.033 & -0.128 \\
\hline Mn liver & -0.523 & 0.677 & 0.331 & 0.036 \\
\hline Zn liver & 0.131 & 0.620 & 0.531 & -0.563 \\
\hline $\mathrm{Cr}$ liver & 0.989 & 0.128 & 0.028 & -0.041 \\
\hline Co liver & 0.424 & -0.632 & -0.431 & -0.425 \\
\hline Cd liver & -0.168 & -0.966 & 0.166 & 0.054 \\
\hline As liver & $-0,329$ & $-0,890$ & 0,237 & 0,209 \\
\hline $\mathrm{Pb}$ liver & 0.919 & 0.095 & 0.020 & 0.083 \\
\hline
\end{tabular}

${ }^{\mathrm{a}}$ Only variables with loadings 0.5 (in bold text) were considered components of the factors

was found to be associated with antioxidant responses in the liver (GSH), with antioxidant responses in the gills (GPx), and with genotoxicity in kidney and neurotoxicity (AChE inhibition). Estimation of F4 scores showed that high levels of $\mathrm{Zn}$ in muscle associated with oxidative damage in the kidney are relevant for specimens from P5, while $\mathrm{Zn}$ in the liver associated with antioxidant responses and damage are relevant for specimens from P2 and P3. 
Table 4 Factor scores estimated for each of the sampling stations in partially dry (P), dry (D), and rainy (R) seasons evaluated in the APA-CIP to the centroid of all cases for the original data

\begin{tabular}{lllll}
\hline Station & F1 & F2 & F3 & F4 \\
\hline \multicolumn{2}{l}{ Partially dry season } & & & \\
P2P & -1.444 & -0.001 & 0.406 & - \\
P3P & 0.106 & -0.280 & -1.469 & - \\
P4P & 0.602 & 1.341 & 0.297 & - \\
P5P & 0.735 & -1.059 & 0.765 & - \\
Dry season & & & & \\
P1D & -0.709 & -0.343 & -1.484 & - \\
P3D & -0.175 & -0.714 & 0.115 & - \\
P4D & 1.739 & -0.170 & -0.099 & - \\
P5D & -0.229 & 1.752 & 0.143 & - \\
P6D & -0.625 & -0.524 & 1.324 & - \\
Rainy season & & & & \\
P1R & 1.876 & 0.195 & 0.040 & 0.169 \\
P2R & 0.370 & 0.152 & 0.039 & -0.550 \\
P3R & -0.603 & 0.296 & -1.376 & -1.183 \\
P4R & -0.332 & -1.977 & 0.316 & 0.115 \\
P5R & -0.579 & 0.506 & -0.633 & 1.775 \\
P6R & -0.732 & 0.829 & 1.614 & -0.326 \\
\hline
\end{tabular}

\section{Discussion}

The current study shows that rainfall seasonality plays an important role in the estuarine pollution of the APA-CIP in terms of the risk of exposure for the biota. The evidence includes the association of metal burdens in muscle and liver tissues as well as the association of PAH levels in the bile of $C$. spixii with the biomarker responses in target tissues. The spatial distribution of biomarker responses and pollutants that bioaccumulated in fish tissues changed throughout the year, a result which indicates that levels and/or bioavailability of these contaminants change according to the season. Although the climate in the region is classified as tropical rainforest with high humidity throughout the year, the present study shows that the differences in rainfall between seasons are enough to influence the environmental quality of the APACIP.

During the dry season, biomarker responses and metal burdens in muscle and liver tissues were generally higher in the sections of the APA-CIP around the city of Cananéia. In addition, $C$. spixii from areas closer to the RIR also were found to possess increased molecular damages in lipids and DNA. Previous studies in coastal areas subjected to seasonal rainfall variation reported that, though the amount of contaminants may decrease with lesser continental inputs during the dry season, the concentration of contaminants in the aquatic system may increase if freshwater inflow is diminished (Sainz et al. 2004; Fianko et al. 2007; Costas et al. 2011).
During the rainy season, biomarker responses and metal burdens in liver and muscle tissues from fishes are more evident in fish from sampling stations under the highest influence of the RIR. The BRI also showed that the alterations are greater during the rainy season compared to the other seasons. Increased rainfall during the rainy season leads to a higher contribution of the RIR to the APA-CIP, which may remobilize metals from the sediment and/or carry metals from landbased sources into the estuary. Previous studies have shown the major role played by rainstorms in the release of contaminants from surface soils into the RIR and its tributaries within the RIR basin (Corsi and Landim 2003; Cunha et al. 2007; Costa et al. 2009; Abessa et al. 2014).

In general, the levels of metals $(\mathrm{Zn}, \mathrm{Cu}, \mathrm{Zn}, \mathrm{Cd}$, and $\mathrm{Pb})$ in the muscle and liver tissues found in the current study were higher than the levels previously reported for $C$. spixii collected in a sampling site that corresponds to the site $\mathrm{P} 3$ of current research (Azevedo et al. 2012). Exceptions were $\mathrm{Cu}$ in muscle, which was not detected in both studies, and $\mathrm{Zn}$ in liver, which was higher in the previous study (from 100.15 to $850.77 \mathrm{mg} \mathrm{kg}^{-1}$ ) (Azevedo et al. 2012).

Although the RIR basin is a natural metal-rich geological area, evidence suggests that the increased levels of metals in fish tissues observed in this study were due to human activities in the river basin. High levels of metals $(\mathrm{Pb}, \mathrm{Zn}, \mathrm{Cu}, \mathrm{Cr}, \mathrm{As})$ recorded in river waters, bottom sediments, and suspended sediments were largely linked to mining activities in the river headwaters (Eysink et al. 1988; Corsi and Landim 2003; Moraes 2004; Guimarães and Sígolo 2008). In the estuary, metals in sediments have been generally found only at moderate levels (Mahiques et al. 2009; Azevedo et al. 2011; Cruz et al. 2014); however, these values have increased substantially since the opening of the Valo Grande channel and even more so after industrial mining activities began (Mahiques et al. 2009). These reports show that metals in the APA-CIP are largely from anthropogenic sources.

Our results suggest the influence of rainfall seasonality on the bioaccumulation of metals and bioavailability of PAHs, though some physiological disturbances may also indicate that some changes are due to seasonal differences. Some DNA damages in fishes exposed to low temperatures may be explained by decreased protein synthesis, which results in less efficient DNA repair mechanisms (Benincá et al. 2012; Pellacani et al. 2006; Buschini et al. 2003). Although the austral winter presented lower water temperatures $\left(21^{\circ} \mathrm{C}\right)$ if compared to the rainy season $\left(28^{\circ} \mathrm{C}\right)$, this difference could not explain the effects on C. spixii described in the current study. In fact, it is more reasonable to assign DNA damages to pollutant exposure, as demonstrated above, than to suggest that lower temperatures alone could give rise to these effects on DNA.

Data integration using FA/PCA revealed that metal concentrations in the body of $C$. spixii are associated with antioxidant 
responses, oxidative damage, neurotoxicity, and genotoxicity. $\mathrm{Zn}, \mathrm{As}$, and $\mathrm{Mn}$ followed by $\mathrm{Pb}, \mathrm{Co}$, and $\mathrm{Cd}$ were the contaminants that were most frequently associated with biomarker responses in C. spixii. Other metals, including $\mathrm{Ni}, \mathrm{Cu}$, and $\mathrm{Cr}$, showed some association with biomarkers, though less frequently. In results that corroborate our study, a previous study showed that $\mathrm{Pb}$ and $\mathrm{Cd}$ levels in the muscle tissues of two catfish species (C. spixii and Genidens genidens) from the APA-CIP were comparable to a highly polluted estuary located within the Santos Estuarine System (Azevedo et al. 2012).

The induction of antioxidant enzymes present in different organs of $C$. spixii were associated with $\mathrm{Zn}, \mathrm{As}, \mathrm{Mn}$, and $\mathrm{Pb}$ that had bioaccumulated in liver and muscle tissues, a finding which suggests both acute and chronic exposure. The relationship between metal exposure and antioxidant response has long been established (Livingstone 2001). Metals can stimulate the production of reactive oxygen species (ROS) through different pathways, such as NADPH oxidases, metalcatalyzed oxidation systems via Fenton reactions (Lushchak 2011; Sharma and Dietz 2009), or even the depletion of major antioxidants in the cell, particularly thiol-containing molecules (Atli and Canli 2010; Stohs et al. 2001). Consequently, increased ROS production triggers the cell defense mechanisms by increasing the activity of antioxidant enzymes, such as superoxide dismutase (SOD), catalase (CAT), GST, and GPx, and also by increasing the expression of free-radical scavenger molecules (e.g., GSH). These responses can be used as biomarkers of a cellular pro-oxidant state.

This method has been validated for cases of waterborne exposure in both field and laboratory studies with fish, as reported by Nunes et al. (2014) in the gills of Anguilla anguilla exposed to $\mathrm{Pb}, \mathrm{Cu}$, and $\mathrm{Cd}$; by Eroglu et al. (2014) in the liver of Oreochromis niloticus exposed to $\mathrm{Cd}, \mathrm{Cu}, \mathrm{Cr}$, $\mathrm{Pb}$, and $\mathrm{Zn}$; and by Eyckmans et al. (2011), who described the induction of antioxidant responses in different freshwater fishes exposed to $\mathrm{Cu}$. According to Fonseca et al. (2014), marine or estuarine fish species respond to waterborne or sediment exposure to metal, and metal was found to induce antioxidant responses in Dicentrarchus labrax, Solea senegalensis, and Pomatoschistus microps. Similar findings were reported Souza et al. (2013) in a study on Centropomus paralellus from two estuaries along the Brazilian coast.

In the current study, the induction of antioxidant mechanism in all of the tissues considered was most evident in the liver, followed by the gills and less frequently in the kidney. Previous studies on fishes also found that antioxidant responses in the liver are more responsive to pollution than in other organs, as described in a study on Zacco platypus after waterborne exposure to $\mathrm{Cu}$ (Kim et al. 2014), as well as in a study on $O$. niloticus, whose liver presented a higher sensitivity than its kidney (Atli and Canli 2010). The liver is a key organ in evaluating the effects of pollutants in fish (Bernet et al. 1999). Hepatocytes are known to exhibit a more efficient antioxidant mechanism because the multiple functions increase the metabolism in the tissue and, consequently, function as a constant source of oxidant species (Gül et al. 2004; Avci et al. 2005).

In the gills of $C$. spixii, antioxidant activity was more responsive to metal bioaccumulation than it was in the kidney. Fish gills are areas of extensive epithelium that exhibit high permeability to ions per unit of surface area, and they are continuously ventilated to allow for the exchange of gases, ions, salts, and water with the environment (Hill et al. 2004). Therefore, this organ is in direct contact with contaminants present in the aquatic milieu, and it is the main organ for contaminant absorption (Sayeed et al. 2003). The current data show that antioxidant responses are associated with an increase of LPO in the gills, a finding which demonstrates the failure of these antioxidant responses to neutralize oxidative species. However, the prevalent pattern is one of increased gill damage (DNA damage and/or LPO) associated with decreased antioxidant activity in this organ, a result which clearly reflects the risk of exposure experienced by fishes living in the estuary around both the RIR and the diffuse and point sources located within the city of Cananéia. The susceptibility of the gills to pollutants, as described in the current study, means that there is a real risk of exposure for the local biota and an environmental health problem. Other studies have corroborated the same findings in the gills of other fish, including as Solea solea from the Tunisia coast (Jebali et al. 2013), O. niloticus from heavily contaminated sites in Egyptian lakes (Abdel-Moneim et al. 2012), and A. anguilla after exposure to metal-rich effluent from a bleached kraft pulp mill (Santos et al. 2004). The increased LPO in the gills suggests that the gills have a less developed antioxidant mechanism compared to the liver and the kidneys.

Current organ-specific responses support that organspecific changes might be related to the exposure route as well the mode of entry and chemical uptake and bioaccumulation by the individuals (Ahmad et al. 2006). The results of FA/PCA suggested that the responses of antioxidant defenses and oxidative damage to metal exposure are different in the studied organs. In higher metal exposure (denoted by higher metal levels in C. spixii body), the liver showed increased antioxidant activity though less oxidative damage than the other organs; on the contrary, gill shows poorer association between antioxidant induction and metal loads in tissues, and a stronger association of metals and oxidative damage. In addition, antioxidant responses in gill in some instances (especially closer to contamination sources) are inhibited when oxidative damage is higher. Therefore, $C$. spixii describes that the liver shows more efficient antioxidant responses, and thus partially protects itself from oxidative damage, while the gills are more susceptible to oxidative damages. Meanwhile, the kidney did not represent a good target organ because fewer 
associations of antioxidant responses, macromolecular damages, and metal body burdens were observed in FA/ PCA. Although the current study showed that the biomarker responses in kidney of $C$. spixii were poorly associated to metals and As levels in tissues in this mildly contaminated estuarine area, it is known that fish kidney plays key homeostatic functions, and its antioxidant response is highly relevant to avoid a temporary or permanent derangement of homeostasis (Vieira et al. 2012).

The results regarding neurotoxicity showed that $\mathrm{Mn}$ and $\mathrm{Pb}$ in muscle tissues and $\mathrm{Zn}, \mathrm{Pb}$, and $\mathrm{Cr}$ in liver tissues are related with a decrease in AChE activity. Other researchers have highlighted the use of AChE activity in fish as a useful biomarker for studying the effect of toxic metals, such as neurotoxic chemicals, in the field (Payne et al. 1996; Fasulo et al. 2010). The current study found that $\mathrm{Pb}$ is most clearly associated with neurotoxicity. $\mathrm{Pb}$ is recognized as an environmentally toxic chemical that causes many biological consequences such as mutation, chromosome aberration, cancer, neurotoxicity, and birth defects (Hong et al. 2007; Nunes et al. 2014). Similar to the current study, previous studies have reported AChE inhibition in fishes exposed to $\mathrm{Pb}$. The decrease in AChE activity has been attributed to the fact that metals can bind to the functional groups of the enzyme, an action which leads to enzyme activity inhibition and a consequent overstimulation of the acetylcholine (ACh) receptors (De Lima et al. 2013; Richetti et al. 2011). The physiological consequences include several adverse effects, such as movement impairment, respiratory failure (WHO/IPCS/INCHEM 1987), or even behavioral changes such as a loss of prey capture ability (Mager et al. 2010). Other results of ACh receptor overstimulation include an increase in peristaltic movement, muscle weakness, tremor, hypertension, and cardiovascular collapse (Boelsterli 2007).

The lowest levels of AChE activity were usually observed in fish collected in the areas around the RIR that contribute to metal exposure, including the area where mining activities were intense in the river headwaters for decades. The high quantity of metals reflects the fact that a large amount of contaminants have been introduced into the APA-CIP from land-based sources. Additionally, this hydrographical basin is an important agricultural area in Brazil, a factor which means that other contaminants could potentially affect $\mathrm{AChE}$ activity not measured in the present study. Two classes of pesticides in particular can affect AChE activity: organophosphorus compounds and carbamates, which are used as an insecticide and an herbicide, respectively (Payne et al. 1996). DDTs were also used in the region on a large scale until the early 1980s, and metabolites are still present (Yogui et al. 2003).

The increased levels of metallothionein-like proteins in different organs were associated with higher metal body burdens in C. spixii. The metal scavenging role of MTs is well established, and the induction of their expression is a recognized biomarker of exposure to metals (Van der Oost et al. 2003; Viarengo et al. 2000; Stegeman et al. 1992). In the current study, the association between MT expression and metal bioaccumulation was more evident in the gills of specimens from sites closer to the city of Cananéia during dryer seasons and in those closer to the RIR during the rainy season. The data clearly show that the levels of MT expression are correlated with the levels of metal bioaccumulation, a result which corroborates the use of this biomarker in areas affected by metals. The higher metal body burdens in C. spixii associated with high levels of liver MTs in sites closer to the river during the rainy season may be explained by the release of metals that had accumulated in the sediment during the mining activities in the past. The explanation of the same result in specimens from sites closer to the city (P4 and P5) during the dry season could be the concentration of metals resulting from urban activities.

On the other hand, during the driest season, levels of metals in the organisms seem to decrease MT levels in the liver. The literature also reports decreased MT levels in fishes as a consequence of exposure to high metal concentrations (Carvalho et al. 2012; Romeo et al. 1997). This finding may be explained by an increased demand of cysteine residues for GSH synthesis during metal detoxification (Romeo et al. 1997).

In the gills of C. spixii, the strong evidence of high levels of MTs with metal bioaccumulation and lipid peroxidation suggests that this organ is an important target for metals in the APA-CIP. These findings show that metals are relevant contaminants in the estuary and that the activities along the river basin and in the cities located on the coast are important sources of pollutants. Therefore, from these results, and in light of a previous study showing high levels of metals $(\mathrm{Pb}$, $\mathrm{Zn}, \mathrm{Cu}$, and $\mathrm{Cr}$ ) in suspended sediments at the upper RIR as well as at its mouth (Guimarães and Sígolo 2008), it is possible to argue that metal-associated suspended particles may be an important uptake route of these contaminants for fishes in the protected area.

MTs behavior in both the liver and the gills, which is associated with metal body burdens, is in accordance with the other biomarkers in that it reflects two main sources of pollution in the APA-CIP: the city of Cananéia and the Ribeira do Iguape River. Additionally, the seasons also sometimes play an important role in the bioaccumulation of metals, depending on the site studied. The current findings corroborate the study by Cruz et al. (2014) in which the sediment quality of the APA-CIP was assessed using ecotoxicological tools. The study concluded that the contamination from both the RIR and urban areas (the city of Cananéia) are relevant sources of pollution in the APA-CIP.

Although metals may be the main class of contaminants affecting fish health in the APA-CIP, the presence of PAHs 
in the bile of $C$. spixii indicates that fishes living in the estuary were exposed to PAHs. PAH metabolites in fish bile are useful for indicating chronic exposure to pyrogenic or petrogenic PAHs (Oliveira Ribeiro et al. 2005; Osório et al. 2014). The increase of LPO in the liver and gills and the genotoxicity in the gills were associated with high levels of PAHs in specimens from the estuary. However, these associations were more discreet than the associations between metals and damages in macromolecules. The increased levels of PAH metabolites in bile were found in individuals from the studied sites closer to the city of Cananéia (sites 4, 5, and 6). This finding strongly suggests that PAHs from urban sources, when combined with metals, lead to LPO increases and DNA damage in the liver of $C$. spixii specimens living in the APA-CIP. Sources of PAH in this area include nautical structures (marinas, decks, nautical garages, and small docks), ferry boat stations, a nautical gas station, municipal sewage discharges, and urban drainage (Cruz et al. 2014). PAHs are of concern in MPAs since they are potentially carcinogenic (Shailaja and D'Silva 2003) and may induce hepatic lesions, physiological disorders, and biochemical disorders in fish (Oliveira Ribeiro et al. 2005).

The BRI ranks showed that the greater alteration in biomarkers responses (i.e., smaller rank values) occurred in the sites $\mathrm{P} 1$ and P4, during the rainy season. During the partially dry and dry seasons, although there is a trend of increasing alteration in the sites near the RIR mouth and the Cananéia City, only minor differences from the reference site (P3) can be observed. It provided a classification of "no or slight alteration from normal responses" for almost all sites (following classification provided by Hagger et al. 2008). Thus, although the BRI is interesting to assist the interpretation of multiple biomarkers data for assessing environmental conditions, the index was not very sensitive and such situation may lead to a false-negative judgment.

The biological effects seen in fish from the estuary after natural exposure to a diversity of pollutants confirm the potential risk of exposure as described previously by Rodrigues et al. (2013) and Araujo et al. (2013). In the APA-CIP, the present study shows that, in addition to the pollution from RIR inputs, the city located within the Environmental Protected Area is another important pollution source that affects this important ecosystem.

Water chemistry and microbiological parameters are the water quality indicators recommended by the International Union for Conservation of Nature and Natural Resources (IUCN) for pollution assessment in MPAs (Pomeroy et al. 2005). Biological indicators are also recommended, but they are not specific to assess the health of fish exposed to contaminants. The results of the current study suggest that biomarker analyses in fish are useful tools for assessing effectiveness and for environmental quality monitoring of MPAs subjected to contamination pressure. This finding is important because they suggest that, even if contaminants in MPAs are at only moderate levels, they are still harmful to fishes in many instances. In these cases, shifting the assessment from agents (e.g., measuring contaminant levels) to targets (biota) can provide useful information for protective management.

It is important to evaluate sublethal responses combined with metal body burdens in tissues and PAHs in bile in order to assess how pollution affects the environment. This study adds to the knowledge on the effectiveness of MPA management. Such tools provide information for making sound decisions regarding environmental health status in vulnerable or valuable marine areas, and they support the development of MPAs and policies for them.

\section{Conclusions}

The current study shows that a set of biomarker analyses using different fish organs is a useful tool for assessing chemical pollution in an MPA. This is the first study on MPAs in which both biomarker responses and metal body burdens, or PAHs, in C. spixii reflected seasonal variation. During the dry season, antioxidant responses, LPO, genotoxicity, and MTs, combined with metal body burdens, clearly showed that fishes were affected in areas under the influence of the city of Cananéia (P4, P5, and P6); during the rainy season, the evidence is clearly present in sampling stations under the highest influence of the RIR (P1, P2, P3). In addition, the current study shows that PAHs from the city may have been causing LPO as well as DNA damages. The studies of AChE activity reinforce these data and include a new finding: lead may be the most relevant neurotoxicity-causing metal in C. spixii. Liver tissue was more responsive in terms of antioxidant responses, whereas the gills were found to be more responsive to biomarkers of effects. The BRI ranks showed that the greater alteration in biomarkers responses (i.e., smaller rank values) occurred in the sites $\mathrm{P} 1$ and $\mathrm{P} 4$, during the rainy season. However, BRI only showed minor alterations in almost all sites, which may lead to false-negative judgments. Finally, the use of sensitive biological tools to assess environmental quality provides useful information for the sound management of a valuable marine protected area.

Acknowledgments The authors wish to thank the Brazilian agency, known as the Comissão de Aperfeiçoamento de Pessoal de Nível Superior (CAPES), for granting a Ph.D. scholarship and the Brazilian institution, known as the Fundação de Amparo a Pesquisa do Estado de São Paulo (FAPESP), for the financial support for this research (FAPESP \#09/ 52762-6). We are also grateful to the USP Oceanography Institute for providing support for field work in Cananéia.

Conflict of interest The authors declare that they have no conflict of interest. 


\section{References}

Aas A, Beyer J, Goksoyr A (2000) Fixed wavelength fluorescence (FF) of bile as a monitoring tool for polyaromatic hydrocarbon exposure in fish: an evaluation of compound specificity, inner filter effect and signal interpretation. Biomarkers 5:9-23. doi:10.1080/ 135475000230505

Abdel-Moneim AM, Al-Kahtani MA, Elmenshawy OM (2012) Histopathological biomarkers in gills and liver of Oreochromis niloticus from polluted wetland environments, Saudi Arabia. Chemosphere 88:1028-1035. doi:10.1016/j.chemosphere.2012.04. 001

Abessa DMS, Gonçalves L, Fernando C et al (2014) Sediment geochemistry and climatic influences in a river influenced by former mining activities: the case of Ribeira de Iguape River, SP-PR, Brazil. Open J Water Pollut Treat 1(1):43-54

Ahmad I, Pacheco M, Santos MA (2006) Anguilla anguilla L. oxidative stress biomarkers: an in situ study of freshwater wetland ecosystem (Pateira de Fermentelos, Portugal). Chemosphere 65:952-962. doi: 10.1016/j.chemosphere.2006.03.042

ANVISA-Agência Nacional de Vigilância Sanitária (National Health Surveillance Agency) (2013) Alimentos. Portaria n 685, de 27 de agosto de 1998(*). Parcialmente revogada pela Resolução-RDC n. 42, de 29/08/2013. Available from http://portal.anvisa.gov.br/wps/ portal/anvisa/anvisa/home/alimentos/!ut/p/c4/04_SB8K8xLLM9 MSSzPy8xBz9CP0os3hnd0cPE3MfAwMDMydnA093Uz8z00B A3cvA_2CbEdFADQgSKI!/?1 dmy\&urile $=$ wcm $\% 3$ Apath $\% 3 \vec{A} /$ anvisa+portal/anvisa/inicio/alimentos/publicacao+alimentos/ contaminantes

Araújo FG (1988) Distribuição, abundância relativa e movimentos sazonais de bagres marinhos (Siluriformes, Ariidae) no estuário da lagoa dos Patos (RS), Brasil. Rev Bras Zool 5(4):509-543

Araujo GS, Moreira LB, Morais RD et al (2013) Ecotoxicological assessment of sediments from an urban marine protected area (XixováJapuí State Park, SP, Brazil ). Mar Pollut Bull 75:62-68. doi:10. 1016/j.marpolbul.2013.08.005

Atli G, Canli M (2010) Response of antioxidant system of freshwater fish Oreochromis niloticus to acute and chronic metal $(\mathrm{Cd}, \mathrm{Cu}, \mathrm{Cr}, \mathrm{Zn}$, Fe) exposures. Ecotoxicol Environ Saf 73:1884-1889. doi:10.1016/ j.ecoenv.2010.09.005

Au DWT (2004) The application of histo-cytopathological biomarkers in marine pollution monitoring: a review. Mar Pollut Bull 48:817-834. doi:10.1016/j.marpolbul.2004.02.032

Avci A, Kaçmaz M, Durak I (2005) Peroxidation in muscle and liver tissues from fish in a contaminated river due to a petroleum refinery industry. Ecotoxicol Environ Saf 60:101-105. doi:10.1016/j.ecoenv. 2003.10.003

Azevedo JS, Braga ES, Favaro DT et al (2011) Total mercury in sediments and in Brazilian Ariidae catfish from two estuaries under different anthropogenic influence. Mar Pollut Bull 62:2724-2731. doi:10.1016/j.marpolbul.2011.09.015

Azevedo JS, Sarkis JES, Hortellani MA, Ladle RJ (2012) Are catfish (Ariidae) effective bioindicators for $\mathrm{Pb}, \mathrm{Cd}, \mathrm{Hg}, \mathrm{Cu}$ and $\mathrm{Zn}$ ? Water Air Soil Pollut 223:3911-3922. doi:10.1007/s11270012-1160-2

Barhoumi B, Clérandeau C, Gourves P-Y et al (2014) Pollution biomonitoring in the Bizerte lagoon (Tunisia), using combined chemical and biomarker analyses in grass goby, Zosterisessor ophiocephalus (Teleostei, Gobiidae). Mar Environ Res 101:184-195. doi:10. 1016/j.marenvres.2014.07.002

Ben Ameur W, de Lapuente J, El Megdiche Y et al (2012) Oxidative stress, genotoxicity and histopathology biomarker responses in mullet (Mugil cephalus) and sea bass (Dicentrarchus labrax) liver from Bizerte Lagoon (Tunisia). Mar Pollut Bull 64:241-251. doi:10. 1016/j.marpolbul.2011.11.026
Benincá C, Ramsdorf W, Vicari T et al (2012) Chronic genetic damages in Geophagus brasiliensis exposed to anthropic impact in estuarine lakes at Santa Catarina coast - southern of Brazil. Environ Monit Assess 184:2045-2056. doi:10.1007/s10661-011-2098-3

Bernet D, Schmidt H, Meier W et al (1999) Histopathology in fish: proposal for a protocol to assess aquatic pollution. J Fish Dis 22:25-34. doi:10.1046/j.1365-2761.1999.00134.x

Beyer J, Petersen K, Song Y et al (2014) Environmental risk assessment of combined effects in aquatic ecotoxicology: a discussion paper. Mar Environ Res 96:81-91. doi:10.1016/j. marenvres.2013.10.008

Boelsterli AU (2007) Mechanistic toxicology. The molecular basis of how chemicals disrupt biological targets. CRC Press, Boca Raton

Boersma PD, Parrish JK (1999) Limiting abuse: marine protected areas, a limited solution. Ecol Econ 31:287-304. doi:10.1016/S09218009(99)00085-3

Bradford MM (1976) A rapid and sensitive method for the quantitation microgram quantities of protein utilizing the principle of protein-dye binding. 254:248-254

Brazil (2012) Recomendação No 05 de 25/06/2012 do Comitê Nacional de Zonas Úmidas. Brasília

Buschini A, Carboni P, Martino A, Poli P, Rossi C (2003) Effects of temperature on baseline and genotoxicant induced DNA damage in haemocytes of Dreissena polymoha. Mutat Res 537:81-92. doi: 10.1016/S1383-5718(03)00050-0

Carvalho CDS, Bernusso VA, de Araújo HSS et al (2012) Biomarker responses as indication of contaminant effects in Oreochromis niloticus. Chemosphere 89:60-69. doi:10.1016/j.chemosphere. 2012.04.013

Carr MH, Neigel JE, Estes JA, Andelman S, Warner RR, Largier JL (2003) Comparing marine and terrestrial ecosystems: implications for the design of coastal marine reserves. Ecol Appl 13:90-107

CEPAGRI (Centro de Pesquisas Meteorológicas e Climáticas Aplicadas à Agricultura) (2014) Clima dos Municípios Paulistas. http://www. cpa.unicamp.br/outras-informacoes/clima_muni_113.html. Accessed 15 October 2014

Chapman PM, Wang F (2001) Assessing sediment contamination in estuaries. Environ Toxicol Chem 20:3-22. doi:10.1002/etc. 5620200102

Chou CL, Paon LA, Moffatt JD et al (2004) Distribution of contaminants in biota and sediments in the Musquash Estuary, Atlantic Canada, marine protected area site initiative and contaminant exclusion zone. Mar Pollut Bull 48:884-893. doi:10.1016/j.marpolbul.2003.11.012

Choueri RB, Cesar A, Torres RJ et al (2009) Integrated sediment quality assessment in Paranaguá Estuarine System, Southern Brazil. Ecotoxicol Environ Saf 72:1824-1831. doi:10.1016/j.ecoenv.2008. 12.005

Cicin-Sain B, Belfiore S (2005) Linking marine protected areas to integrated coastal and ocean management: a review of theory and practice. Ocean Coast Manag 48:847-868. doi:10.1016/j.ocecoaman. 2006.01.001

Conti ME, Cecchetti G (2003) A biomonitoring study: trace metals in algae and molluscs from Tyrrhenian coastal areas. Environ Res 93: 99-112. doi:10.1016/S0013-9351(03)00012-4

Corsi AC, Landim PMB (2003) Chumbo, Zinco e Cobre em sedimentos de corrente nos Ribeirões Grande, Perau e Canoas, e Córrego Barrinha no município de Adrianopólis (Vale do Ribeira, PR). Geociências 22:49-61

Costa PM, Diniz MS, Caeiro S et al (2009) Histological biomarkers in liver and gills of juvenile Solea senegalensis exposed to contaminated estuarine sediments: a weighted indices approach. Aquat Toxicol 92:202-212. doi:10.1016/j.aquatox.2008.12.009

Costas M, Prego R, Filgueiras AV, Bendicho C (2011) Land-ocean contributions of arsenic through a river-estuary-ria system (SW Europe) under the influence of arsenopyrite deposits in the fluvial basin. Sci 
Total Environ 412-413:304-314. doi:10.1016/j.scitotenv.2011.10. 034

Cruz ACF, Davanso MB, Araujo GS et al (2014) Cumulative influences of a small city and former mining activities on the sediment quality of a subtropical estuarine protected area. Environ Monit Assess 186: 7035-7046. doi:10.1007/s10661-014-3908-1

Cunha I, Neuparth T, Caeiro S, Costa M, Guilhermino L (2007) Toxicity ranking of estuarine sediments on the basis of Sparus aurata biomarkers. Environ Toxicol Chem 26:444-453. doi:10. 1897/06-119R.1

Cunha-Lignon M, Coelho-Jr C, Almeida R, Menghini R, Correa F (2009) Mangrove forests and sedimentary processes on the South Coast of São Paulo State (Brazil). J Coast Res 405-409

De Lima D, Roque GM, de Almeida EA (2013) In vitro and in vivo inhibition of acetylcholinesterase and carboxylesterase by metals in zebrafish (Danio rerio). Mar Environ Res 91:45-51. doi:10. 1016/j.marenvres.2012.11.005

Duarte CA, Giarratano E, Amin OA, Comoglio LI (2011) Heavy metal concentrations and biomarkers of oxidative stress in native mussels (Mytilus edulis chilensis) from Beagle Channel coast (Tierra del Fuego, Argentina). Mar Pollut Bull 62:1895-1904. doi:10.1016/j. marpolbul.2011.05.031

EC-European Commission (2002) Commission Regulation N 178/2002 of 28 January 2002. Laying down the general principles and requirements of food law, establishing the European Food Safety Authority and laying down procedures in matters of food safety. Off $\mathrm{J}$ Eur Union Legis Ser L031:1-24. Available from: http://eurlex.europa. eu/LexUriServ/LexUriServ.do?uri=CELEX:32002R0178

EC-European Commission (2006) Commission Regulation N. 1881/ 2006 of 19 December 2006. Setting maximum levels of certain contaminants in foodstuff. Off J Eur Union Legis Ser 65:5-24, http://eurlex.europa.eu/legal-content/EN/ALL/?uri=CELEX:32006R1881

Ellman GL, Courtney KD, AndresV FRM (1961) A new and rapid colorimetric determination of acetylcholinesterase activity. Biochem Pharmacol 7:88-95

Environment Canada and Ministère du Développement durable, de l'Environnement et des Parcs du Québec (2007) Criteria for assessment of sediment quality in Quebec and application frameworks: prevention, dredging and remediation. $41 \mathrm{pp}$

Eroglu A, Dogan Z, Kanak EG et al (2014) Effects of heavy metals (Cd, $\mathrm{Cu}, \mathrm{Cr}, \mathrm{Pb}, \mathrm{Zn}$ ) on fish glutathione metabolism. Environ Sci Pollut Res Int. doi:10.1007/s11356-014-2972-y

Eyckmans M, Celis N, Horemans N et al (2011) Exposure to waterborne copper reveals differences in oxidative stress response in three freshwater fish species. Aquat Toxicol 103:112-120. doi:10.1016/j. aquatox.2011.02.010

Eysink GGJ, Pádua HB, Piva-Bertoletti SAE, Martins MC, Navas-Pereira D (1988) Metais pesados no vale do ribeira e em iguape-cananéia. Ambiente 2(1):6-13

FAO/WHO-Food and Agriculture Organization/World Health Organization (2014) Contaminants \& food additives. Limit test for heavy metals in food additive specifications - explanatory note. Available from: http://www.fao.org/food/food-safety-quality/ scientific-advice/jecfa/guidelines0/en/

Fasulo S, Marino S, Mauceri A et al (2010) A multibiomarker approach in Coris julis living in a natural environment. Ecotoxicol Environ Saf 73:1565-1573. doi:10.1016/j.ecoenv.2010.01.008

Favaro LF, Frehse FA, Oliveira RN, Schwarz R Jr (2005) Reprodução do bagre amarelo, Cathorops spixii (Agassiz) (Siluriformes, Ariidae), da Baía de Pinheiros, região estuarina do litoral do Paraná, Brasil. Rev Bras Zool 22:1022-1029. doi:10.1590/S010181752005000400030

Fianko JR, Osae S, Adomako D et al (2007) Assessment of heavy metal pollution of the Iture estuary in the central region of Ghana. Environ Monit Assess 131:467-473. doi:10.1007/s10661-006-9492-2
Fishbase (2014) Cathorops spixii (Agassiz, 1829). http://www.fishbase. org/summary/SpeciesSummary.php?id=960. Accessed 30 October 2014

Fonseca VF, Vasconcelos RP, França S et al (2014) Modeling fish biological responses to contaminants and natural variability in estuaries. Mar Environ Res 96:45-55. doi:10.1016/j.marenvres.2013.10.011

Fraschetti S, Terlizzi A, Micheli F et al (2002) Marine protected areas in the Mediterranean Sea: objectives, effectiveness and monitoring. Mar Ecol 23:190-200. doi:10.1111/j.1439-0485.2002.tb00018.x

Gagne F, Blase C (1995) Evaluation of the genotoxicity of environmental contaminants in sediments to rainbow trout hepatocytes. Environ Toxicol Water Qual 10:217-229. doi:10.1002/tox.2530100309

García-Álvarez N, Boada LD, Fernández A, Zumbado M, Arbelo M, Sierra E, Xuriach A, Almunia J, Camacho M, Luzardo OP (2014) Assessment of the levels of polycyclic aromatic hydrocarbons and organochlorine contaminants in bottlenose dolphins (Tursiops truncatus) from the eastern atlantic ocean. Mar Environ Res 100: 48-56. doi:10.1016/j.marenvres.2014.03.010

García Charton JA, Williams ID, Pérez Ruzafa A, Milazzo M, Chemello R, Marcos C, Kitsos MS, Koukouras A, Riggio S (2000) Evaluating the ecological effects of Mediterranean marine protected areas: habitat, scale and the natural variability of ecosystems. Environ Conserv 27:159-178. doi:10.1017/S0376892900000199

Giarratano E, Duarte CA, Amin OA (2010) Biomarkers and heavy metal bioaccumulation in mussels transplanted to coastal waters of the Beagle Channel. Ecotoxicol Environ Saf 73:270-279. doi:10. 1016/j.ecoenv.2009.10.009

Guimarães V, Sígolo JB (2008) Associação de resíduos da metalurgia com sedimentos em suspensão-rio Ribeira de Iguape. Rev Inst Geociênc 8(2):1-10

Gül S, Belge-Kurutaş E, Yildiz E et al (2004) Pollution correlated modifications of liver antioxidant systems and histopathology of fish (Cyprinidae) living in Seyhan Dam Lake, Turkey. Environ Int 30: 605-609. doi:10.1016/S0160-4120(03)00059-X

Hagger JA, Jones MB, Lowe D, Leonard DRP, Owen R, Galloway TS (2008) Application of biomarkers for improving risk assessments of chemicals under the water framework directive: a case study. Mar Pollut Bull 56:1111-1118. doi:10.1016/j.marpolbul.2008.03.040

Hill RW, Wyse GA, Anderson M (2004) External respiration: the physiology of breathing. In: Hill RW, Wyse GA, Anderson M (eds) Animal physiology, 1st edn. Sinauer Associates Inc, Sunderland

Hong F, Wu C, Liu C et al (2007) Direct evidence for interaction between lead ions and kidney DNA from silver crucian carp. Chemosphere 68:1442-1446. doi:10.1016/j.chemosphere.2007.04.020

Houde ED (2001) Committee on the evaluation, design, and monitoring of marine reserves and protected areas in the United States. marine protected areas, tools for sustaining ocean ecosystems. National Academy of Sciences, Washington, DC

IBGE (Instituto Brasileiro de Geografia e Estatística) (2014) Estimativas de população por cidades. http://cidades.ibge.gov.br/xtras/home. php. Accessed 30 October 2014

Jebali J, Sabbagh M, Banni M et al (2013) Multiple biomarkers of pollution effects in Solea solea fish on the Tunisia coastline. Environ Sci Pollut Res Int 20:3812-3821. doi:10.1007/s11356-012-1321-2

Keen JH, Habig WH, Jakoby WB (1976) Mechanism for the several activities of the glutathione S-transferases. J Biol Chem 251:61836188

Keller DF, Gleason E, McLeod CM et al (2009) Climate change, coral reef ecosystems, and management options for marine protected areas. Environ Manag 44:1069-1088. doi:10.1007/s00267-0099346-0

Kim W-K, Park J-W, Lim E-S et al (2014) Tissue-specific antioxidant responses in pale chub (Zacco platypus) exposed to copper and benzo[a]pyrene. Bull Environ Contam Toxicol 92:540-545. doi: 10.1007/s00128-014-1213-x 
King J, Alexander F, Brodie J (2013) Regulation of pesticides in Australia: the Great Barrier Reef as a case study for evaluating effectiveness. Agric Ecosyst Environ 180:54-67. doi:10.1016/j. agee.2012.07.001

Livingstone DR (2001) Contaminant-stimulated reactive oxygen species production and oxidative damage in aquatic organisms. Mar Pollut Bull 42:656-666. doi:10.1016/S0025-326X(01)00060-1

Long ER, MacDonald DD, Smith SL, Calder FD (1995) Incidence of adverse biological effects within ranges of chemical concentrations in marine and estuarine sediments. Environ Manag 19(1):81-97

Lushchak VI (2011) Environmentally induced oxidative stress in aquatic animals. Aquat Toxicol 101:13-30. doi:10.1016/j.aquatox.2010.10. 006

Mager EM, Brix K V, Grosell M (2010) Influence of bicarbonate and humic acid on effects of chronic waterborne lead exposure to the fathead minnow (Pimephales promelas). 96:135-144. doi: 10.1016/ j.aquatox.2009.10.012

Mahiques MM, Burone L, Figueira RCL et al (2009) Anthropogenic influences in a lagoonal environment: a multiproxy approach at the Valo Grande mouth. Cananéia-Iguape system (SE Brazil). Braz J Oceanogr 57(4):325-337. doi:10.1590/S1679-87592009000400007

Malins DC, Anderson KM, Stegeman JJ, Jaruga P, Green VM, Gilman NK, Dizdaroglu M (2006) Biomarkers signal contaminant effects on the organs of english sole (Parophrys vetulus) from puget sound. Environ Health Perspect 114(6):823-829. doi:10.1289/ehp.8544

Maranho LA, Pereira CDS, Choueri RB et al (2012) The application of biochemical responses to assess environmental quality of tropical estuaries: field surveys. J Environ Monit 14:2608-2615. doi:10. 1039/c2em30465a

Mercosul - Mercado Comum do Sul (2011) GMC N²12/2011, Regulamento técnico mercosul sobre limites máximos de contaminantes inorgânicos em alimentos. Available from: http:// www.agricultura.gov.br/arq_editor/file/CRC/Mercosul $\% 20-\%$ 20 G M C - RES \% 20n \% 2012-2011\%20-\%201imites\% 20contaminantes $\% 20$ inorg $\%$ C3\%A2nicos $\% 20 \mathrm{em} \% 20$ alimentos. pdf

Michel P, Averty B, Andral B, Chiffoleau JF, Galgani F (2001) Tributyltin along the coasts of Corsica (Western Mediterranean) : a persistent problem. Mar Pollut Bull 42:1128-1132. doi:10.1016/S0025326X(01)00101-1

Mora C, Sale P (2011) Ongoing global biodiversity loss and the need to move beyond protected areas: a review of the technical and practical shortcoming of protected areas on land and sea. Mar Ecol Prog Ser 434:251-266. doi:10.3354/meps09214

Morachis-Valdez G, Dublán-García O, López-Martínez LX et al (2015) Chronic exposure to pollutants in Madín Reservoir (Mexico) alters oxidative stress status and flesh quality in the common carp Cyprinus carpio. Environ Sci Pollut Res Int. doi:10.1007/s11356014-4061-7

Moraes MBR (2004) Área de Proteção Ambiental—APA como agência de desenvolvimento sustentável: APA Cananéia-Iguape-Peruíbe/ SP. Fapesp, São Paulo

Morais LG, Abessa DMS (2014) PSR framework applied to the coastal management of "Complexo Estuarino- Lagunar Iguape-Cananéia"CELIC (São Paulo, Brazil), in terms of sanitation and public health. Gestão costeira integrada. doi:10.5894/rgci455

Nunes B, Capela RC, Sérgio T et al (2014) Effects of chronic exposure to lead, copper, zinc, and cadmium on biomarkers of the European eel, Anguilla anguilla. Environ Sci Pollut Res Int 21:5689-5700. doi:10. 1007/s11356-013-2485-0

Oliva M, José Vicente J, Gravato C et al (2012) Oxidative stress biomarkers in Senegal sole, Solea senegalensis, to assess the impact of heavy metal pollution in a Huelva estuary (SW Spain): seasonal and spatial variation. Ecotoxicol Environ Saf 75:151-162. doi:10. 1016/j.ecoenv.2011.08.017
Oliva M, Gravato C, Guilhermino L et al (2014) EROD activity and cytochrome P4501A induction in liver and gills of Senegal sole Solea senegalensis from a polluted Huelva estuary (SW Spain). Comp Biochem Physiol C Toxicol Pharmacol 166:134-144. doi: 10.1016/j.cbpc.2014.07.010

Olive PL (1988) DNA precipitation assay: a rapid and simple method for detecting DNA damage in mammalian cells. Environ Mol Mutagen 11:487-495. doi:10.1002/em.2850110409

Oliveira Ribeiro CA, Vollaire Y, Sanchez-chardi A, Roche H (2005) Bioaccumulation and the effects of organochlorine pesticides, PAH and heavy metals in the eel (Anguilla anguilla) at the Camargue Nature Reserve , France 74:53-69 doi: 10.1016/j.aquatox.2005.04. 008

Osório FHT, Silva LFO, Piancini LDS et al (2014) Water quality assessment of the Tubarão River through chemical analysis and biomarkers in the Neotropical fish Geophagus brasiliensis. Environ Sci Pollut Res Int 21:9145-9160. doi:10.1007/s11356-013-1512-5

Palmer MA, Allan JD, Butman CA (1996) Dispersal as a regional process affecting the local dynamics of marine and stream benthic invertebrates. Trends Ecol Evol 11:322-326

Payne JF, Mathieu A, Melvin W, Fancey LL (1996) Acetylcholinesterase, an old biomarker with a new future? Field trials in association with two urban rivers and a paper mill in Newfoundland. Mar Pollut Bull $32: 225-231$

Pellacani C, Buschini A, Furlini M et al (2006) A battery of in vivo and in vitro tests useful for genotoxic pollutant detection in surface waters. J Aquat Toxicol 77:1-10. doi:10.1016/j.aquatox.2005.10.010

Pereira CDS, Abessa DMS, Choueri RB et al (2014) Ecological relevance of Sentinels' biomarker responses: a multi-level approach. Mar Environ Res 96:118-126. doi:10.1016/j.marenvres.2013.11.002

Perra G, Pozo K, Guerranti C et al (2011) Levels and spatial distribution of polycyclic aromatic hydrocarbons (PAHs) in superficial sediment from 15 Italian marine protected areas (MPA). Mar Pollut Bull 62: 874-877. doi:10.1016/j.marpolbul.2011.01.023

Pinsino A, Torre C Della, Sammarini V (2008) Sea urchin coelomocytes as a novel cellular biosensor of environmental stress : a field study in the Tremiti Island Marine Protected Area, Southern Adriatic Sea, Italy 541-552 doi: 10.1007/s10565-008-9055-0

Pomeroy RS, Watson LM, Parks JE, Cid G (2005) How is your MPA doing? A methodology for evaluating the management effectiveness of marine protected areas. Ocean Coast Manag 48:485-502. doi:10. 1016/j.ocecoaman.2005.05.004

Pozo K, Lazzerini D, Perra G et al (2009) Levels and spatial distribution of polychlorinated biphenyls (PCBs) in superficial sediment from 15 Italian Marine Protected Areas (MPA). Mar Pollut Bull 58:773-776. doi:10.1016/j.marpolbul.2009.03.003

Ramos-Gómez J, Coz A, Viguri JR, Luque A, Martín-Díaz ML, DelValls TÁ (2011) Biomarker responsiveness in different tissues of caged ruditapes philippinarum and its use within an integrated sediment quality assessment. Environ Pollut 159:1914-1922. doi:10.1016/j. envpol.2011.03.030

Richetti SK, Rosemberg DB, Ventura-Lima J et al (2011) Acetylcholinesterase activity and antioxidant capacity of zebrafish brain is altered by heavy metal exposure. Neurotoxicology 32:116122. doi:10.1016/j.neuro.2010.11.001

Rodrigues SK, Abessa DMS, Machado EC (2013) Geochemical and ecotoxicological assessment for estuarine surface sediments from Southern Brazil. Mar Environ Res 91:68-79. doi:10.1016/j. marenvres.2013.02.005

Romeo M, Cosson RP, Gnassia-barelli M et al (1997) Metallothionein determination in the liver of the sea bass Dicentrarchus labrax treated with copper and B[a]P. Mar Environ Res 44:275-284

Sainz A, Grande JA, De Torre ML (2004) Characterisation of heavy metal discharge into the Ria of Huelva. Environ Int 30:557-566. doi:10. 1016/j.envint.2003.10.013 
Santos MA, Pacheco M, Ahmad I (2004) Anguilla anguilla L. antioxidants responses to in situ bleached kraft pulp mill effluent outlet exposure. Environ Int 30:301-308. doi:10.1016/S0160-4120(03) 00178-8

Sayeed I, Parvez S, Pandey S, Bin-Hafeez B, Haque R, Raisuddin S (2003) Oxidative stress biomarkers of exposure to deltamethrin in freshwater fish, Channa punctatus Bloch. Ecotoxico Environ Saf 56:295-301. doi:10.1016/S0147-6513(03)00009-5

Scherl LM, Wilson A, Wild R, Blockhus J, Franks P, McNeely JA, McShane TO (2006) As áreas protegidas podem contribuir para a redução da pobreza? Oportunidades e limitações. IUCN, Gland

Sedlak J, Lindsay R (1968) Estimation of total, protein-bound, and nonprotein sulfhydryl groups in tissue with Ellman's reagent. Anal Biochem 25:192-205

Shailaja MS, D'Silva C (2003) Evaluation of impact of PAH on a tropical fish, Oreochromis mossambicus. Chemosphere 53:835-841. doi:10. 1016/S0045-6535(03)00667-2

Sharma SS, Dietz K-J (2009) The relationship between metal toxicity and cellular redox imbalance. Trends Plant Sci 14:43-50. doi:10.1016/j. tplants.2008.10.007

Sies H, Koch OR, Martino E, Boveris A (1979) Increased biliary glutathione disulfide release in chronically ethanol-treated rats. FEBS Lett 103:287-290

Souza I, Duarte I, Pimentel N (2013) Matching metal pollution with bioavailability, bioaccumulation and biomarkers response in fish (Centropomus parallelus) resident in neotropical estuaries. Environ Pollut 180:136-144. doi:10.1016/j.envpol. 2013.05.017

Stegeman JJ, Brouwer M, Richard TDG et al (1992) Molecular responses to environmental contamination: enzyme and protein systems as indicators of chemical exposure and effect. In: Huggett RJ, Kimerle RA, Mehrle PM Jr, Bergman PM (eds) Biomarkers: biochemical, physiological and histological markers of anthropogenic stress. Lewis Publishers, Boca Raton

Stohs SJ, Bagchi D, Hassoun E, Bagchi M (2001) Oxidative mechanisms in the actin depolymerization. Toxicol Appl Pharmacol 139:115-121
Tabachnic BG, Fidell LS (1996) Using multivariate statistics. Harper Collins College Publishers, New York

Terlizzi A, Delos AL, Garaventa F, Faimali M, Geraci S (2004) Limited effectiveness of marine protected areas: imposex in hexaplex trunculus (Gastropoda, Muricidae) populations from Italian marine reserves. Mar Pollut Bull 48(1-2):188-192. doi:10.1016/j. marpolbul.2003.10.019

UNCLOS (1982) United Nations Convention on the Law of the Sea Law of the Sea Convention. Montego Bay, Jamaica

USEPA (United States Environmental Protection Agency) (1994) Determination of trace elements in waters and wastes by inductively coupled plasma-mass spectrometry. Washington, Environmental Protection Agency. Method 200:9

Van der Oost R, Beyer J, Vermeulen NPE (2003) Fish bioaccumulation and biomarkers in environmental risk assessment: a review. Environ Toxicol Pharmacol 13:57-149. doi:10.1016/ S1382-6689(02)00126-6

Viarengo A, Ponzano E, Donderob F, Fabbrih R (1997) A simple spectrophotometric method for metallothionein evaluation in marine organisms: an application to Mediterranean and Antarctic molluscs. 44:69-84

Viarengo A, Burlando B, Ceratto N, Panfoli I (2000) Antioxidant role of metallothioneins: a comparative overview. Cell Mol Biol 46:407417

Vieira MC, Torronteras R, Córdoba F, Canalejo A (2012) Acute toxicity of manganese in goldfish Carassius auratus is associated with oxidative stress and organ specific antioxidant responses. Ecotoxicol Environ Saf 78:212-217. doi:10.1016/j.ecoenv.2011.11.015

WHO/IPCS/INCHEM (1987) Organophosphorus insecticides: a general introduction. Environ Health Crit 63World Health Organization, Geneva

Wills ED (1987) Evaluation of lipid peroxidation in lipids and biological membranes. In: Snell K, Mullack B (eds) Biochemical toxicology: a practical approach. IRL Press, Oxford

Yogui GT, de Oliveira Santos MC, Montone RC (2003) Chlorinated pesticides and polychlorinated biphenyls in marine tucuxi dolphins (Sotalia fluviatilis) from the Cananéia estuary, southeastern Brazil. Sci Total Environ 312:67-78. doi:10.1016/S0048-9697(03)00198-0 